\title{
Contextos cotidianos para el arte Cuadros y objetos de arte para el adorno doméstico madrileño a mediados del siglo XVIII
}

\author{
JESUSA VEGA \\ Universidad Autónoma de Madrid
}

Si históricamente ha habido un arte que ha luchado por ser noble este ha sido el de la pintura. A defender su excelencia y nobleza dedicaron tanto Pacheco como Carducho sus esfuerzos. Así, cuando en la actualidad se habla de cuadro a nadie le entra duda de que se trata de pintura, pero no siempre fue de esta manera. A mediados del siglo xviII el cuadro era una colgadura que recibía un tratamiento relativamente diferenciado del resto de los objetos de adorno o amueblamiento de la casa. Se vendía, por lo general, en los mismos establecimientos que éstos, daban razón de ellos los mismos sujetos y se renovaba como el resto del ajuar doméstico cuando el propietario deseaba estar a la moda. Estas cuestiones son las que van a ocuparnos en las páginas siguientes sirviéndonos de base la información suministrada por el Diario curioso-erudito y comercial. Público y económico, conocido comúnmente como el Diario de Madrid ${ }^{1}$. Según se declaraba en el sexto punto del plan de publicación, redactado por Manuel Ruiz de Uribe, se recogieron con atención las ainvenciones curiosas y necesarias de los artistas liberales y mecánicos: v. gr. un pintor, que saca de su oficina un lienzo primoroso, u otra cualquiera pintura exquisita; un dorador, un tallista, un cerrajero, un ebanista o cualquiera otro artífice liberal o mecánico, que se halle con algún primoroso efecto de su aplicación, estudio y trabajon.

No sorprende el dinamismo que se aprecia a través del periódico en la compraventa de objetos de arte entre 1758 y 1769 . Fueron unos años en los que el consumo de bienes, además de la polémica sobre el lujo, trajo una renovación del gusto en la decoración de los interiores domésticos. El proceso de cambio que tiene lugar en los palacios y residencias de la corona - buen exponente es el nuevo rumbo que se aprecia en el arte de la tapicería - se hizo extensivo a otras casas nobles y cortesanas. La política de gasto doméstico de las gentes ricas y acomodadas en el

1 Algunas noticias fueron publicadas en su día por E. V. H. (1959: 189-205). 
consumo de "géneros costosos para su lucimiento, comodidad y regalo" era bien recibida, según los estudiosos de la época (Sarrailh 1974: 244 y ss), si era prudente. No así las ansias de renovación, convertidas en un verdadero afán de ostentación, de las mujeres cuando contraían matrimonio. En opinión de algunos coetáneos, las nuevas esposas hacían que tan pronto como se firmaban los capítulos matrimoniales fuera "necesario pensar luego en transformar la casa, pintar nuevos frisos, enrasar lo techos, dorar hasta los corredores más excusados, rehacer la vajilla a la moda y poner en superfluos aparadores la mitad del imperio de la China; y para todos estos despropósitos hacen tributarios a los graneros, venden por nada los muebles antiguos a los prenderos y destierran de toda la casa lo que tenga el más leve resabio de añejo ${ }^{2}$. De esta situación quedó fiel reflejo en el nuevo periódico surgido igualmente como consecuencia de ese dinamismo comercial.

No pretendemos aventurar qué ocurre en las décadas siguientes ${ }^{3}$, pero lo cierto es que las noticias y los anuncios de ventas de objetos de adorno que se dan en la publicación se reducen drásticamente a partir de la década de los setenta. Aunque no cabe suponer que desapareciera este tipo de actividad - prenderías y tiendas debían estar abiertas todo el añoes muy posible que se normalizara, se redujera su impacto diario y conociera una regulación. La venta debía cobrar mayor vida en otoño, durante los días que duraba la Feria de Madrid, aunque parece que ya era habitual en estos años ir al Rastro. Robert Darley Waddilove, clérigo y amigo de Lord Grantham -embajador inglés en Madrid entre 1771 y 1779-, iba allí a buscar cuadros y objetos de arte, incluso era conocido por las gangas que conseguía en las adquisiciones de este tipo de mercancías ${ }^{4}$. Por la información que se desprende del periódico, en lo que se refiere a la venta de objetos de arte, además existía la prendería, el prendero que podríamos denominar ambulante, los sujetos encargados de dar razón de los objetos en venta, y particulares que ofertaban bienes aislados o abrían pública almoneda por traslado o defunción.

\footnotetext{
2 Nipho, Cajón de sastre, t. IV, pp. 77-78, citado en Martín GaITe (1981: 35).

3 Téngase presente que a comienzos de la década de los ochenta la inestabilidad política debió provocar un retraimiento generalizado en los gastos suntuarios. Hasta el mismo monarca, por real orden de 15 de marzo de 1780, ordenó que se dejara en suspenso la pintura de originales para tejer en la Real Fábrica, ocupada en aquel entonces en producir tapices para renovar el adorno de múltiples cuartos de los diferentes palacios.

4 Ha quedado testimonio de estas actividades en la correspondencia de Grantham en Wrest Park Paper, depositados en Bedfordshire Record Office (GLENDINNING, HaRRIS y RUSSELL 1999).
} 
Parece interesante detenerse en ver cómo se daban a conocer a través del Diario Noticioso tanto las prenderías como las almonedas. En estos años sabemos que existían varias prenderías estables en Madrid. La primera que aparece en las páginas del periódico [3.febrero.1758] es la que se encontraba en la calle de Fuencarral, ubicada frente al barbero establecido frente a los Agonizantes. Debía ser una de las más importantes de la ciudad pues era uno de los comercios de referencia dentro de la calle. No conocemos el nombre del propietario, en ningún caso se publicó, pero este anonimato es bastante habitual. Por esta misma razón resultan singulares los casos de Tomás Fernández que tenía su prendería en la calle del Duque de Alba [7.marzo.1758]; de Manuel del Valle cuya prendería se encontraba a la altura de los estudios del Colegio Imperial de la Compañía, en la acera opuesta, era la primera de la calle si se andaba en dirección al Rastro [30.agosto.1758]; y de Miguel de Sevilla propietario de la prendería situada en la espalda del convento de la Pasión de los Dominicos, en la Plazuela de la Cebada [27.noviembre.1758]. Siguiendo un orden cronológico, según los comunicados que van publicándose en el periódico, además de los mencionados, existían los siguientes establecimientos: en la calle del Príncipe junto a la cerería y cuartel [17.marzo.1758]; en la esquina de la calle del Pez, en el lado opuesto a la puerta por donde sacaban las sillas del Refugio [19.abril.1758]; en la calle de las Tabernillas de San Francisco, pasada la escuela de los Doctrinos [29.mayo.1758]; en la calle de la Magdalena, donde estaba la fuente de Relatores junto a la botica [26.septiembre.1758]; en la plazuela de Antón Martín, junto a la capilla del Santísimo Cristo de la Salud [18.octubre.1758]; en la calle de Fuencarral, frente a la casa del Marqués de Murillo, entre un cerrajero y un carpintero [7.noviembre.1758]; en la calle de la Ruda [25.noviembre.1758]; en la calle de la Luna, frente de la Botillería [24.enero.1759]; en la calle de Toledo, como se iba a la Cava Alta, junto a la zapatería [23.febrero.1761]; inmediata a la Aduana [29.agosto.1761]; en la calle de Atocha en el lado opuesto a Nuestra Señora del Loreto [5.octubre.1761]; en la corredera de San Pablo frente a la casa del Marqués de Andía [1.diciembre.1762]; en la calle del Carmen a la altura de la calle de los Negros [28.marzo.1764]; en la calle Fuencarral frente de la capilla de Nuestra Señora de la Soledad [7.marzo.1765], que probablemente era la misma que se situaba al otro lado de la calle de las Infantas [9.julio.1766]; y en la plazuela de Santo Domingo [28.marzo.1767].

Además existían prenderos sin tienda abierta al público. Solían establecerse en algún punto más o menos fijo de la ciudad. Así encontramos al que se ponía a la puerta de los Consejos [10.junio.1758]; el que se situaba junto a Lonja del Convento de la Santísima Trinidad Calzada [25.no- 
viembre.1758], y el que se establecía en la esquina de la Inclusa [19.julio.1760]. Estos comerciantes, más que tener la mercancía junto a ellos, eran una fuente de información y daban razón a quien se interesara de aquellos objetos que estaban a la venta, por lo general, en casas particulares. Ésta era también una actividad propia de los prenderos con tienda estable, pero, además, en estos locales se podían encontrar todo tipo de objetos.

Entre las imágenes de la vida madrileña que legó Goya se encuentra el cartón para tapiz La feria de Madrid. Aunque de fecha más tardía - la factura fue presentada a comienzos de enero de 1779-, merece ser recogida la descripción de la visita ${ }^{5}$ a la prendería dada por el pintor: "delante de ella el prendero tratando de la venta de una alhaja con una señora a quien acompañan dos caballeros, el uno con un anteojo mirando ciertos cuadros que hay en venta, detrás de éstos se descubren otros cuatro y a más distancia varias gentes". La excepcional capacidad de síntesis de Goya le permitió hacer un inventario visual de los bienes que se encontraban a la venta en estos establecimientos. Si hiciéramos un retrato ideal de lo que se ofertaba en estos años, sumando los artículos que se van dando a conocer a través del periódico, el resultado sería el siguiente: abundaban las tapicerías, paños sueltos o completas, incluidas sobrepuertas, rinconeras y vueltas bordadas. Entre las tapicerías que se hallaban en venta las había historiadas - por ejemplo la serie de ocho paños con los Trabajos de Hércules o los quince de la Historia de David, ambas tejidas en Bruselas - o simplemente de motivos decorativos como arboledas, ramilleteros, columnas, figuras chicas, etc. (destaca entre estas últimas una tapicería de montería que se componía de trece paños) ${ }^{6}$. Igualmente era fácil encontrar colgaduras de China, bordadas en seda, o lienzos de Indias, como los doce óvalos que se ofrecieron y que representaban "diferentes figuras de hombres". Del mobiliario destaca el elevado número de muebles de charol, ya fuera encarnado o negro, procedentes en ocasiones de Inglaterra: tocadores, cofres, papeleras, biombos, etc. Existían también bufetes para despacho; para la casa se encontraban allí fácilmente colchones, camas (algunas imperiales colgadas de damasco carmesí), alfombras, todo tipo de cornucopias y espejos, lo necesario para la chimenea ${ }^{7}$, desde la mampara suelta hasta los juegos a la moda franceses de

5 La visita a la feria de Madrid como escenario social ha sido estudiada por TOMMLINSON (1993: 91 y ss.).

6 Sobre el cambio de gusto en las tapicerías véase HERRERo (1996: 80-82).

7 Parece que hasta la década de los noventa no se comenzó a generalizar la instalación en las casas madrileñas de las nuevas chimeneas y estufas francesas e ingle- 
morillo o murillos con todo lo correspondiente, braseros de pies y taburetes, algunos de ellos de red hechos en Inglaterra (recuérdese que todavía había costumbre en las casas de sentarse a la morisca las mujeres y no había desaparecido completamente el estrado) ${ }^{8}$.

Entre los muebles especiales se pueden citar dos monetarios umuy exquisitos, hechos a la inglesa, con mesas correspondientes" y un reclinatorio. Había objetos curiosos como una "arquita de tapa guarnecida por dentro de terciopelo carmesí y galones de oro, repartida en varios nichos y divisiones para poner plata", un abanico "de pintura de Roma, con varillaje de nácar guarnecidas de chapas de oro y dos diamantes brillantes en las guías", un reloj "de faltriquera, hecho en Londres", etc.

Debía ser bastante común encontrar estampas y láminas de cobre grabadas en estas prenderías. Entre ellas eran habituales las que se conocían como rubenes, fruto de la maquinaria reproductora que montó el propio pintor, y, por lo general, eran siempre de tema religioso ${ }^{9}$. Pero no cabe pensar que esto ocurría sólo entre las estampas porque lo cierto es que entre los objetos de arte el tema religioso era habitual, tanto en pintura como en escultura, donde se suele dar un mayor detalle y concreción sobre lo que representa. Aunque el tema de la escultura le dejemos para mejor ocasión, parece interesante señalar que las más abundantes eran las figuras conocidas como niños de Nápoles, en realidad pequeños niños Jesús (en muchas ocasiones niños de Pasión), y san Juanito con el Cordero. Se podían adquirir sueltos y solos, aunque por lo general se ofrecían con sus peanas y sus urnas. En las urnas cabían desde las más sencillas con sus cristales hasta las elaboradas con buenas maderas y adornadas con embutidos de concha; solían descansar sobre mesas haciendo juego.

sas —el arquitecto y vecino de Madrid Raimundo Yaneli insertó un largo anuncio en el Diario de Madrid el 22 de noviembre de 1796-, entre cuyas ventajas se encontraba un consumo más bajo y menos humo (con claras ventajas para la salud de los vecinos), más fuego y menos incendios. Fueron progresivamente sustituyendo el uso del brasero.

8 Sin duda es elocuente la siguiente descripción dada por Casanova durante su estancia en Madrid en 1768: «Doña Ignacia, cortés, se levantó del suelo, donde estaba sentada con las piernas cruzadas, como las africanas: costumbre de los moros que todavía permanece. He visto en Madrid a mujeres de buena cuna sentarse de esta forma sobre el entarimado, y sobre todo en las antecámaras de la Corte y en la del palacio de la princesa de Asturias. Las españolas se sientan sobre las piernas en las iglesias, donde no hay ni bancos ni sillas; tienen una agilidad sorprendente para pasar de esta posición a prosternarse de rodillas, o a levantarse, y viceversa", CASANOva (1982: t.v, 130). Sobre el estrado en el siglo ilustrado véase Martín GaITE (1981: 27 y ss).

9 Este tema ha sido tratado en PORTÚs y VEGA (1998: especialmente el capítulo III). 
Finalmente se encontraban las pinturas. Como se ve en la descripción de Goya, algunas de ellas se colgaban a la puerta del establecimiento al abrir la prendería —es fácil también apreciar en la fachada la percha para colgar la mercancía y el clavo vacío en primer término, además al prendero se le retrata con la garrocha para acercar lo que no estaba a la mano. En más de una ocasión allí debieron quedarse olvidadas cuando se echaba el cierre, expuestas al antojo de cualquiera. Así reza el siguiente aviso aparecido el 1 de diciembre de 1762: "La persona que hubiere encontrado un cuadro con la Imagen de nuestra Señora de la Concepción de vara y media de largo y sin marco, que se quedó olvidado, colgado en la pared el día 25 del próximo pasado de noviembre en la Corredera de San Pablo, en una Prendería que está frente de la casa del Señor Marqués de Andía, la persona que lo hubiere encontrado acuda para la restitución a dicha prendería en donde se dará el hallazgo".

Prenderías y prenderos estaban también pendientes de las almonedas, incluso en ocasiones eran ellos los que daban razón de dónde se celebraban. El horario de visita a estos domicilios era de mañana y tarde -desde las 8 o las 10 horas hasta las 13 , y entre las 14 y las 17 horas hasta las oraciones, o la caída del sol. Entre las personas extranjeras que abrieron almoneda de sus bienes en estos años se pueden citar: el cónsul de Inglaterra [18.septiembre.1758]; el Príncipe Yachi, embajador de la corte en Nápoles [5.junio.1761]; y el embajador de Venecia cuando llegó el momento de abandonar la Corte [15.julio.1768]. Daba razón de los bienes de este último su mayordomo, Juan Antonio Trabé y, entre los enseres, se encontraban espejos, arañas, cornucopias, guarniciones de uso y de gala, berlinas de uso y carrozas de gala, sillerías doradas y otros muebles". Interesante era la relación de alhajas para el adorno de la casa que puso a la venta el 4 de octubre de 1763 el Príncipe Repnin, ministro plenipotenciario de la corte de Rusia, a través del agente José Ferreti Caracciolo junto al ayuda de cámara Mr. Thimofee:

la vajilla de plata, la vajilla de porcelana de Sajonia y el desert de lo mismo, otros juegos de porcelana de Sajonia, otra porción de china de Japón, y rara, para las chimeneas y gabinete; todo lo perteneciente a la caballeriza, con sus mulas, caballos y coches; diferentes muebles de París, como son camas grandes y pequeñas, sillería, canapés, duquesas, cabriolés, relojes etc., la repostería, con todos sus utensilios pertenecientes; la batería de cocina, con otras cosas de plata para la mesa, cristales, etc.

Igualmente de algunos nobles de la Corte se dio cuenta que se había abierto almoneda. Entre ellas se puede citar la del conde de Miranda, duque de Peñaranda, domiciliado en la plazuela de la Carbonera. Fue la pri- 
mera en anunciarse en el periódico y estuvo presente durante tres años, lo que puede dar idea del lento proceso de liquidación de este tipo de bienes. Desconocemos el precio en el que se ofertaba la mercancía, menor aún es la información sobre el ajuste final al que se llegaba con el portero José Pola encargado de este cometido. El primer comunicado decía así: "Quien quiera comprar diamantes, algunos trincheros de plata, un gabinete con China, cornucopias, repisas, pinturas, taburetes de charol, y mesas, araña de cristal y otros cuadros aparte de los del gabinete, urnas, con distintos santos y una fuente de concha, guarnecida de bronce, dorado de oro molido con diferentes figuras de lo mismo, una cama con su colgadura de tela de oro" [7.febrero.1758] que, posteriormente, es calificada de "colgadura de cama imperial", cuando además se advertía de la existencia de "distintas cosas de coral" [29.enero.1759]. A finales de 1758, todavía estaba a la venta una batería de cocina de hierro hecha en Inglaterra junto a pinturas "con los marcos dorados", mesas doradas y otros muebles adecuados para el adorno del gabinete [24.noviembre.1758]; y el 5 de mayo del año siguiente se dio otro aviso donde se enumeraba la venta de "tapices, cortinas de damasco y tafetán, alfombras, catres con colgaduras, sillas, canapés, sillas de manos, coches, guarniciones, diamantes, cofres, arañas de cristal, oratorios, gabinetes, pinturas, batería de cocina y repostería", que tampoco debió provocar mucho entusiasmo entre los compradores ya que el 5 de junio de 1759 se repite casi en los mismos términos. Parte de las pinturas de gabinete de variado tamaño continuaban a la venta a finales de septiembre de 1760 , según se desprende del aviso insertado el día 30 de ese mes; lo mismo se puede decir de los tapices pues, el 6 de noviembre del año siguiente, todavía se podían adquirir "Ocho tapices ya usados, los cinco de lampazos y los tres sueltos".

De las ventas de otros miembros de la nobleza se puede señalar la que se estableció en casa del marqués de Santiago el 24 de mayo de 1758, donde se podía adquirir la tapicería de doce paños de la Historia de Jacob, además de "diferentes cuadros de todos los tamaños, originales y copias". El conde de Montijo abrió almoneda el 9 de marzo de 1759 y entre los enseres se encontraban "pinturas exquisitas, rinconeras de gabinete, espejos grandes, con mesas de piedras, sillas, taburetillos de junco de Inglaterran; el 5 de febrero de 1766 en la calle de Valverde, donde murió la marquesa viuda de Montemolín, se vendían varias alhajas como eran "catorce paños de tapiz que representan arboleda, dieciocho sillas de brazos cubiertas de damasco verde, una silla de manos [...] pinturas y otras cosas"; y, finalmente, el 16 de marzo de 1767 se comenzó la venta de los bienes del marqués del Sauce en el cuarto segundo de la casa que habitaba en la calle de Santa Isabel. Allí se podía comprar un forlón azul, 
con sus molduras doradas, forrado en terciopelo carmesí, una silla de manos, escopetas de varios autores de Madrid, espejos, tapicerías, telillas de griseta de lana, un adorno de chimenea francesa tallado y dorado, un adorno de oratorio, un clave exquisito, pinturas, china, un biombo rico y otras distintas cosas de guston. Dos meses más tarde todavía se encontraban los siguientes objetos: aun forlón de gala, un coche forrado en paño encarnado, estatuas de piedra, un guardarropa, figuras de china, un adorno de oratorio, otro de chimenea, distintos cuadros, un biombo, tapicerías de la Historia de don Quijote pintada en angeo ${ }^{10}$, telillas."

Entre las subastas de otros vecinos de la Corte se puede citar la del difunto presbítero Miguel Sancho, domiciliado en la calle de las Pozas esquina a la de la Concepción, frente a la Fuente del Cura, entre cuyos bienes había "varios muebles y pinturas exquisitas"; se pusieron en venta el 10 de febrero de 1759 según se daba noticia en el Diario del día 17 de ese mismo mes. Otro caso sería el del alguacil Eugenio Varrero domiciliado en la Plaza Mayor, portal de Torneros inmediato a la entrada de la Carnicería, donde se hallaba de venta "ropa, pinturas, escultura, una vara de alguacil y otras varias alhajas" [18.mayo.1759]. Tras el fallecimiento de Ignacio de Ortega, Consejero de Órdenes, en su domicilio en la calle de Embajadores, se podían adquirir los once paños de la tapicería con la Historia de Diana, todavía en buen estado, dos alfombras grandes, "pinturas, láminas y otras alhajas de diamantes" [23.septiembre.1761]. Por último, a la casa del Consejo de Castilla se podía ir a comprar los objetos de la almoneda del difunto José del Campo donde se encontrarían diferentes pinturas y otros muebles además de uun coche forlón y una berlina forrados en terciopelo carmesí poco usados" [12.noviembre.1768].

Más interesante parece la venta que se hizo en el cuarto principal de la casa de Juan Rubio, situada en la calle de la Madera baja frente a la casa del duque de Alba, Pedro Estuart. Se vendían "varias pinturas, una muy exquisita y original del Tiziano, otra del Españoletom, las primeras eran de diverso tamaño, la de Tiziano era de un poco más de dos varas de alto y lo mismo de ancho, y la de Ribera representaba "la muerte de Abel que tiene de alto poco más de una vara y de ancho dos y cuarta. Además se encontraban los siguientes enseres: "un biombo hecho en la China, de ocho hojas muy especial, dos papeleras de Maque de Indias, un Crucifijo de marfil [...] una alfombra turca, otra de Orán, varias colchas de Indias", a lo que había que sumar espejos, cortinas y otros varios muebles de la casa [27.febrero, 8.marzo y 26.abril.1759].

Entre las almonedas que sabemos se abrieron por orden judicial se encuentra la de la calle de Atocha, frente al Colegio de Santo Tomás junto

10 Lienzo fabricado en Anjou, empleado normalmente para forrar tapicerías. 
a la librería de Cardama. Allí había "tapicerías, colgaduras, plata, pinturas y otros bienes exquisitos" [14.febrero.1759]. Singulares, aunque anónimas, son dos ventas: la que se estableció el 10 de mayo de 1759 en la calle de las Urosas, al salir a la calle Magdalena donde, además de varias pinturas, mesas de piedras antiguas y una cama colgada de damasco, se encontraba un "Oratorio completo con servidumbre de plata como son 6 candeleros, vinageras, campanilla, cáliz, un pie con las palabras de la consagración y caja para Hostias"; y la situada en la calle de Alcalá esquina a Cedaceros donde se vendía un friso que se compone de 24 tablas de charol de china con figuras de marfil, dos papeleras de lo mismo, cuatro cofres, doce pinturas de lienzo y una cama torneada de palo de santo" [20.abril.1758].

Si nos referimos a la pintura, hubo almonedas que debieron ser espectaculares, como la de la calle de las Huertas, frente a la del Príncipe, en la casa que hacía esquina a la plazuela de Matute. En el cuarto principal y a voluntad de su dueño, en ese momento ausente de la Corte, se vendían varios muebles y además pinturas "de los mejores autores como son de Alberto Durero, del Tiziano, del Españoleto, de Velázquez, del Racionero Cano, de Murillo, de Jordán y de otros autores antiguos y modernos y todo se dará con la mayor moderación de sus valuaciones, estará abierto por mañana y tarde a las horas regulares" [18.febrero.1760]. Pero, por lo común, las pinturas formaban parte del mobiliario de la casa ${ }^{11}$, quedando incorporadas a la venta de los enseres, siendo muy limitada la información que se daba sobre ellas. Expresiones como muchas, diferentes, varias, algunas, o simplemente "pinturas", son bastante comunes; en

1 Sirvan de ejemplo los siguientes avisos: "En la calle de las Infantas, frente de casa del señor marqués de Camarena en el cuarto bajo se venden una porción de barros de Indias, espejos, pinturas y muchos utensilios de cobre y azófar" [5.abril.1758]; "En la calle de Valverde, casa inmediata a la Sacristía del Convento de Religiosas Mercenarias, en el cuarto principal se venden a voluntad de su dueño los muebles siguientes: espejos, cornucopias, pinturas, taburetes, sitiales, espetera, \&c.n, meses más tarde se proseguía aen vender por menor una porción de pinturas y otros muebles, está abierta solamente por la tarde desde las 3 hasta las 5" [26.octubre y 3.noviembre.1758]; "En la calle del Clavel, frente de la Botica, cuarto segundo, casa nueva se ha abierto una almoneda, en la que se hallarán varias cosas de menaje de casa, como también muchas y diferentes pinturas, muy primorosas" [25.enero.1760]; "En la calle de Valverde frente del Estanco Real del Aguardiente y del ebanista en el cuarto segundo se ha abierto una almoneda en la que se hallan particulares pinturas, retratos, muebles del menaje de la casa, diferentes vestidos de hombre y de mujer y otras varias cosas curiosas" [18.septiembre.1762]; "La persona que quisiere comprar varias pinturas originales de dos y tres varas y media de largo y dos y media de ancho con otros muebles de casa acuda para su ajuste a la calle de las Veneras, casa núm. 1 que hace esquina con la de la Sartén" [7.agosto.1764]. 
ocasiones se matizan con algún calificativo sobre su calidad - exquisitas, primorosas, de buen autor o autor conocido ${ }^{12}$-, su tamaño o el posible destino; por ejemplo, en la venta de los bienes del duque de Miranda se diferenciaba entre la pintura que era adecuada para el adorno del gabinete de aquella destinada a otros cuartos o salas de la casa.

La renovación del mobiliario y los elementos de adorno afectaron muy directamente al gabinete por lo que muchas de las ofertas, como se ha podido ir apreciando, se acompañaban con el latiguillo de ser propias o adecuadas para esta pieza de la casa que debemos considerar sucesora, salvando las distancias temporales y espaciales, del oratorio de siglos precedentes. No obstante, aún en esta época se ofertaban objetos que podían servir indistintamente para uno u otro fin. Sirva de ejemplo la singular "urna muy especial dada de charol con el modelo de la Montaña de Montserrate, perfectamente imitada" propia para "oratorio o gabinete" - en el aviso incluso se considera adecuada para una iglesia [17.octubre.1758]—; la oferta de "figuras sueltas de todos géneros y tamaños para adornos de oratorios y gabinetes, su hechura y colorido no es menos primoroso y de gusto que las fabricadas en Roma o Nápoles" [13.diciembre.1758]; o el altar propio para "Oratorio o gabinete" [24.agosto.1767].

A pesar de estas referencias ambiguas, el gabinete era ya una pieza completamente laica, un escaparate más o menos público, lleno de objetos diversos donde se proyectaba y se reconocía el gusto del dueño - téngase presente, como observa Martín Gaite, que una de las circunstancias que había variado en la vida familiar del siglo xviII era la de recibir a los amigos en casa (Martín Gaite 1981: 36). De estas nuevas costumbres se derivaba el deseo de embellecer la casa, incluso de encargar a un especialista que construyese este entorno íntimo. El adornista de gabinete también existía, pero debía ser ésta una actividad suplementaria, no exclusiva, e incluso una alternativa. En cualquier caso, no parece que fuera muy lucrativa, por lo menos cabe hacer esta deducción al leer sendos comunicados dados en el periódico:

En la calle de San Isidro al costado de la fábrica de los cristales entrando por la Carrera de San Francisco entre dos puerta cocheras, cuarto principal, vive un artífice

12 "Se vende una colgadura de seda, hecha en Indias que tiene 140 varas con campo blanco y flores azules y coloradas, un espejo de vestir con su mesa y piedra hecha a toda moda, una araña muy primorosa, un canapé y seis sillas correspondientes a la colgadura, una vajilla de porcelana con dos albornias y sus platos, cuatro docenas y media de trincheros, [...] dos candeleros, [...] dos coches, el uno hechura de París, [...] varias pinturas de autores muy conocidos, para su ajuste se acudirá a la calle de los Reyes, dos puertas más abajo del Tinte, cuarto bajo" [28.marzo.1760]. 
que lo ha sido de dicha fábrica el cual tiene habilidad [...] para colgar las arañas y cornucopias y también para componer gabinetes con mucha curiosidad [27.enero.1761].

en la calle ancha de San Bernardo esquina a la de la Flor baja, casa núm. 3, cuarto principal darán razón de un sujeto muy hábil en adornar salones y gabinetes, que desea acomodarse para guardarropa [14.septiembre.1772].

Se podía comprar un gabinete completo - recuérdese el gabinete con china del conde de Miranda-, pero lo común era que se ofertaran objetos sueltos. Entre los anuncios de gabinete completo se encuentra el siguiente: "La persona que quisiere comprar un gabinete, con su colgadura de pinturas originales de varios autores, países, floreros y pájaros, que se vende por tener que ausentarse el dueño fuera de esta Corte, acuda para su ajuste al librero que está frente de la calle de la Zarza entrando por la de los Preciados" [21.octubre.1763]. Probablemente también se trataba de un gabinete completo el que se puso a la venta en la almoneda que se abrió en el cuarto segundo de la casa situada en la calle de Atocha inmediata a la iglesia de San Juan de Dios [9.octubre.1761] y que estaba compuesto por "veinte pinturas de miniatura, una guarnición de un gabinete, cuatro mesas de talla doradas, unas puertas vidrieras de dicho gabinete, dos floreros dorados para arañan; y el que estaba adornado con las alhajas siguientes: un espejo, cortinas nuevas de estampado amarilla, doce fruteros valencianos y doce cuadros de varias ideas [5.febrero.1762]. Al margen de estos ejemplos, lo común es que se oferte el adorno compuesto "de láminas, pinturas, repisas y otras varias alhajas" [2.octubre.1762].

La idea que podemos dar de esta estancia doméstica a través de la información suministrada en la publicación es de interés porque en este contexto era donde se exponían los objetos de arte según el gusto de la época, téngase presente que lo importante en estos años es que pusiera en evidencia que el propietario estaba a la moda. Por esta razón la estancia podía ser dejada en primer lugar en manos de un ensamblador. Entre los profesionales del ramo se puede citar a "José Soyé, maestro ensamblador de París" quien hacía saber al público que dibujaba y ejecutaba "con primor todo género de obra de arquitectura en toda clase de maderas, para los adornos de iglesias, palacios y casas de señores, como alcobas, gabinetes redondos u ovalados, etc., arreglando las piezas con toda perfección sin tocar a la fábrica y asegurando también las maderas con la mayor delicadeza, pudiéndose quitar y poner, vive en la calle del Soldado, junto al cuartel de reales guardias Walonas" [5.enero.1767].

Diferentes adornistas trabajaron en estos años para el rey en el Palacio Real, aunque el empleo de Adornista de Cámara no se creó hasta el 26 de enero de 1789, cuando fue nombrado Juan Bautista Ferroni. En su 
solicitud del 11 de septiembre de ese mismo año, por la que pide la gracia de llevar uniforme, el mismo explica su ocupación continua «en formar modelos y dibujos para todos los diferentes ramos que abraza como son bronces, madera para régimen de ebanistas, tallistas, estucos, escayola, piedras duras y plateros" ${ }^{13}$. Con motivo de determinadas celebraciones se podía encargar un adorno de gabinete especial; tal fue el caso del Marqués de Estepa quien, con motivo de sus bodas, estrenó un adorno realizado por Felipe Ynza "compuesto todo de mármoles y cristales con varios grabados o sobrepuestos de oro molido" ${ }^{14}$.

El adorno del gabinete podía llegar a ser muy recargado. Se abusaba de telas y estucos, y paulatinamente se fue incorporando el uso de los papeles pintados (como alternativa más económica se empleará el calco o estarcido ${ }^{15}$ ) que vino a desplazar en gran medida el uso de lienzos pintados, que se podían adquirir tanto de primera como de segunda mano. Por ejemplo, el 21 de diciembre de 1758 se daba el siguiente anuncio: "Se venden tapices de lienzo pintado, hechos en la fábrica de este género, de Aragón, de varias calidades, precios y conveniencias conocidas, se harán conforme se pidan y se imitará la idea que se proponga así en tapices, como en colgaduras de camas y alfombras; y el 13 de abril de ese mismo año se encontraban de venta "cuatro tapices de gabinete, pintados en lienzo con zumo de hierbas al uso de Italian. En 1759 residía en la Corte un sujeto extranjero que tenía "habilidad para pintar todo género de tapices, con la circunstancia de que no llegará mosca, ni polilla a ellos, el que pintará de Marina, de Historia y todo cuanto se le pidan ${ }^{16}$.

13 Archivo General de Palacio, Expedientes Personales, Caja 363, exp. 38. Sobre la decoración de los edificios reales véase JUNQuERA (1979).

14 Archivo Histórico de Protocolos de Madrid, p. ${ }^{\circ}$ 18.201, “Obligación de Don Joaquín Ynza a la testamentaria del Marqués de Estepan, fechada el 16 de febrero de 1788 , fol. 168. La decoración de las casas y palacios españoles de la segunda mitad del siglo xviII fue el tema de la conferencia dictada por el profesor Nigel Glendinning en el curso de verano de la Fundación de los Duques de Soria dirigido por J. Brown en el verano de 1992; una vez más toda la información que he precisado me ha sido generosamente facilitada, principalmente las noticias referentes a la documentación que se encuentra en este archivo madrileño, y ha venido acompañada de la amistad y el ánimo que nunca podré agradecer bastante. Felipe Ynza es padre del pintor de origen aragonés Joaquín Ynza.

15 En cuanto al calco o estarcido se empleaban patrones de cartón o de hojalata, con temas vegetales o se imitaban efectos de telas como, por ejemplo, "el damasco en paredes pintadas al temple", Secretos (1807: t. 3, 57).

16 Vivía este sujeto extranjero en la calle de Alcalá, frente al convento de las Religiosas Vallecas, donde existía una maestra de batas [23.febrero.1759]. 
A mediados del siglo XVIII el papel pintado que se empleaba en España era de importación, por lo que su uso era bastante restringido. Según avanza el siglo se va generalizando. Al principio se traía de Francia, Holanda e Inglaterra (Glendinning 1992: 46) ${ }^{17}$. En 1778 la Real Sociedad Aragonesa de Amigos del País premiaba al dorador Martín Sierra por sus muestras de papel pintado. Poco después este último con la ayuda de un capitalista estableció la fabricación de papeles pintados de "toda especie de jaspeados, otros imitados al natural de raíz de olivo, y de diferentes dibujos para gabinetes, habitaciones y demás destinos con más comodidad en el precio que los que vienen del extranjero" ${ }^{18}$.

El éxito creciente del papel pintado llevó al establecimiento en Madrid de diferentes fábricas y de grabadores especializados - por ejemplo, el alemán Joaquín Teiner (Diario de Madrid, 2 de noviembre de 1815) que se estableció en la ciudad a principios de la década de los ochenta. La moda del papel pintado rivalizaba tanto con las telas ricas — colgaduras perfectamente imitadas al terciopelo del ancho del papel y realzadas de oro, otras imitando igualmente al raso, columnas, jarrones de flores, estatuas, camafeos, cenefas" (Gaceta de Madrid, 1 de abril de 1815)- como con la pintura, circunstancia que no escapó al audaz observador de costumbres Ramón de la Cruz, quien en boca de uno de sus personajes puso los siguientes versos:

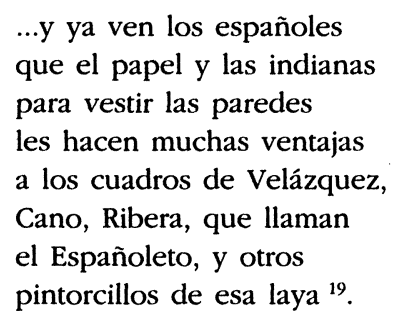

17 La exportación de papel pintado desde Inglaterra a España en la segunda mitad del siglo XviII era mayor que a otros países europeos. Según la información que se conserva en los libros de Aduana ingleses del año 1774 se exportaron sólo 2.800 yardas a Francia, mientras que a Holanda se remitieron 101.296, a Portugal 110.692 y a España 171.859; véase OMAN y HAMILTON (1982: 35).

18 Gaceta de Zaragoza, 21 de octubre de 1783, pp. 345-346. Como observó el profesor Glendinning en su momento, en el surtido de esta fábrica se aprecia la convivencia de dos tradiciones decorativas, por un lado la propia de doradores y estuquistas, es decir, la imitación de mármoles y piedras semipreciosas, y por otro la imitación realista de productos de la naturaleza.

19 Ramón DE LA CRUZ, El petimetre, ed. Durán, t. I, p. 503, citado por MARTín GAITE (1981: 44). 
En resumen, la variedad y riqueza en la producción de papel pintado fue arrinconando otras colgaduras propias del adorno doméstico; tanto en el papel pintado a pincel como en el estampado se llegó a una gran sofisticación, sirva de ejemplo el surtido que ofrecía a principios del siglo XIX la fábrica de Pedro Giroud de Villerte ${ }^{20}$, adornista de cámara:

En la Real fábrica de papeles pintados, sita inmediato al convento de las señoras Comendadoras de Santiago, se hallará un nuevo surtido de colecciones de países pintados al pincel, con trajes nacionales, de mayor tamaño que los que hasta el día ha tenido; igualmente los hay estampados y son las riberas del Bósforo, los pórticos de Atenas, la vista de los monumentos de París, una cacería inglesa, la historia de D. Quijote, los salvajes del mar Pacífico, compuesta sobre los descubrimientos hechos por los capitanes Cook y la Perouse, y otros viajeros, las vistas de Italia, todo perfectamente elaborado: asimismo tiene un gran surtido de colgaduras para salas y gabinetes, todo nuevo y del mayor gusto ${ }^{21}$.

En el gabinete los tonos tendían a ser claros y se buscaba crear un ambiente rico, de lujo real o aparente, y a ello contribuía decididamente la abundancia de objetos dorados: repisas, molduras, muebles, marcos, cornucopias, etc ${ }^{22}$. No es difícil imaginar dicho ambiente cuando se constata que se pusieron a la venta colgaduras de gabinete de seda color

20 Se estableció la fábrica en Madrid gracias a las gestiones del Conde de Aranda cuando era embajador del rey de España en París. Con objeto de propagar esta industria se trasladó a Madrid Pedro Giroud de Villerte, a éste le sucedió primero su hijo Juan Bautista y, tras su fallecimiento en 1792, se hizo cargo su otro hijo Pedro quien la regentó hasta 1826, año en que le sucedió su hijo Segismundo. Pedro Giroud de Villerte fue nombrado adornista de cámara el 26 de agosto de 1800 con derecho a llevar el mismo uniforme que Ferroni. Archivo General de Palacio, Expedientes Personales, caja 435, exp. 38.

21 Diario de Madrid, 1 de noviembre de 1815. Ese mismo año sabemos que la fábrica, que había sido prácticamente desmantelada durante los años de la Guerra de la Independencia, si creemos al propietario, contaba con las siguientes oficinas: la sala donde se unen los pliegos de papel para la formación de los rollos, la sala de los fondos o almacén; la sala para el bruñido, dos obradores para el estampado, un obrador para el terciopelo y realce de oro donde también se molían las lanas teñidas de colores, el laboratorio de colores, la sala de grabado donde los operarios trabajaban sobre madera de peral, el depósito de moldes colocados por número de orden; en el segundo piso estaba el salón adornado de varias muestras de papeles (Gaceta de Madrid, 31 de marzo de 1815).

22 Christian August Fischer observó cómo las pinturas murales dejaban paso a la pintura lisa en las paredes, fundamentalmente al color amarillo. Cada vez se fue haciendo más común pintar paredes y muebles, incluso aumentó el número de víctimas intoxicadas debido a la inhalación de los agentes tóxicos que acompañaba al uso de dorados y barnices en mesas, cómodas, sillas, etc. (FISCHER 1802: 133). 
rosa bordada de plata y oro. A las telas se sumaban los adornos compuestos de "sobrepuertas de Indias, frisos, flores, pájaros y otras cosas de esta naturaleza" que se podían encargar, por ejemplo, a un sujeto que vivía en la plazuela del Ángel [16.febrero.1758], o comprar de segunda mano -recuérdese el friso de veinticuatro tablas de charol de china con figuras de marfil que se encontraba en una almoneda, o cabe citar los frisos y cenefas doradas "construidas a la italiana para adorno de cuarto o gabinete" que se ofertaban el 11 de octubre de 1758. Los frisos se disponían en la parte inferior de la pared, tradicionalmente donde se arrimaba el estrado y tenían una altura de vara o vara y media. Parece que en un principio eran de estera de palma, pero progresivamente se fueron incorporando de lienzo pintado, imitando telas o piedras ricas, de papel pintado, exóticos y de importación. Es frecuente la aparición del friso en los inventarios madrileños de la segunda mitad del siglo xviII y gracias a ello se puede comprobar que había gran variedad en medidas y materiales, todos llevaban media caña dorada y suele incluirse ésta en la tasación del friso, aunque existen excepciones como, por ejemplo, el friso pintado al temple de veinte varas de largo que recibió María del Carmen Revoces vecina de Madrid el 19 de agosto de 1789: el friso se valoró en doscientos reales y la media caña en sesenta y cinco. Podemos dar algunos ejemplos: en casa de Manuel Revilla había un friso de charol de cinco cuartas de alto y ocho varas de largo y otro pintado a la chinesca de ocho varas de largo y vara y cuarta de ancho, fueron tasados en noviembre de 1772 en doscientos y ciento ochenta reales respectivamente ${ }^{23}$. En octubre de 1786 se tasó un friso de papel pintado de diez varas de largo, a real la vara ${ }^{24}$; en agosto de 1789 con valor de ciento ochenta y cinco reales catorce varas de friso pintado al temple ${ }^{25}$ - existían desde luego frisos pintados al óleo-; el friso de charol de china que se componía de ciento cuarenta tablas de a cuarta de ancho, que poseía el Marqués de Pontejos, fue valorado en cuatro mil doscientos reales el 18 de abril de $1800^{26}$; las siete varas de friso "de los Alemanes" y las nueve varas de "friso encerrado a la chinesca" que tenía el matrimonio formado por Juan Crisóstomo Munave y Rosa Barriguette, se tasaron en 1789 en cincuenta y seis reales el primero, y a quince reales

23 Archivo Histórico de Protocolos, p. ${ }^{\circ}$ 19.64, fol. 92r. Revilla y Presa era oficial mayor del Oficio de Correo General y en 1777 era Administrador General de la Casa Arbitrio de Nieve.

24 Archivo Histórico de Protocolos, p. ${ }^{\circ} 21.809$, fol. 126v.

25 Archivo Histórico de Protocolos, p. ${ }^{\circ}$ 20.751, fol. $103 \mathrm{v}$.

26 Archivo Histórico de Protocolos, p. ${ }^{\circ} 16.563$, fol. 173v. 
la vara el segundo ${ }^{27}$; en otros documentos se refieren a este tipo de friso como "un friso fábrica Alemana" ${ }^{28}$.

Los frisos, como el resto de los objetos de adorno, se podían adquirir y también se daban comunicados de venta en el Diario Noticioso. Por ejemplo el 11 de mayo de 1758 se podían comprar en casa del carpintero de la calle del Prado, situada frente de las monjas de Santa Ana, dos frisos de siete a ocho varas pintados al óleo. Resulta evidente que algunos frisos eran traídos de importación pero otros eran de producción local e, incluso, pintados ex profeso para una determinada sala o cuarto. Es muy probable que los doradores que tenían habilidades para pintar se ocuparan de estos menesteres. Tal debía ser el caso de Miguel Lores, domiciliado en la calle de Carretas frente a la de Majaderitos, quien pintaba "con bastante primor" sobre lienzo y cristal [9.febrero.1758], y lo mismo cabe pensar del dorador domiciliado en el cuarto bajo, último portal a mano izquierda, en la calle de la Cruz antes de llegar a la del Gato [15.febrero.1762]. También todos aquellos sujetos hábiles en hacer todo género de charoles se ocuparían en hacer los frisos de este material [9.febrero.1758]; incluso, en alguno de los comunicados de este tipo, se explica que el tal sujeto sabe, además, pintar y dorar adornos de casas o encargarse de limpiarlos [24.enero.1759]. Tenemos certeza de que en la prendería de Tomás Fernández se pintaba "todo género de biombos, frisos, adornos de altares, mesas, papeleras" [7.marzo.1758], y de que en el cuarto principal de la casa nueva situada frente al herrador, "en la calle del Olivar pasado el cuartel de Peñalosa como al medio de la callen, vivía un pintor que ofrecía "pintar al óleo todo género de bosques, países, cabañas, monterías y cualquiera pieza exquisita para adornar gabinetes en lienzo, en lámina en cristal o en cualquiera otra materia" [1.julio.1758]. Entre los comunicados singulares, relativos a la pintura de adorno doméstico, se encuentra el insertado por Pedro Roguié, quien había aencontrado el admirable secreto de pintar sobre cualquier género de seda, en colores tan sólidos y permanentes que no temen la menor impresión del aire" y por ello se ofrecía a pintar, no sólo todo tipo de batas o vestidos de señora, sino también "sillones, taburetes, canapés, gabinetes, y estrados, frontales de altar, casullas, y otros adornos de casas, palacios o templos, para lo cual saca primero los dibujos necesarios a satisfacción de quien guste emplearle" ${ }^{29}$.

27 Archivo Histórico de Protocolos, p. ${ }^{\circ} 21.636$, fol. 119r.

28 Archivo Histórico de Protocolos, p. ${ }^{\circ} 17.645$, fol. 572v.

29 En el momento de ofertar sus servicios -21 de agosto de 1767-, este artífice vivía en la casa número 7 de la calle de San Antón. 
Buena parte de los adornos domésticos, y sobre todo en el gabinete, eran de estuco, material fundamental por ser económico y prestarse a un versátil enmascaramiento que incrementaba el lujo visual. Con respecto al estuco resulta interesante recoger, entre los avisos dados en el periódico, el de un profesional del ramo, redactado en los siguientes términos:

En la calle de los Peregrinos frente de la casa del Exmo. Señor Duque de Arcos, en la posada de Matías, cuarto principal vive un sujeto que tiene habilidad especial para hacer obras de estuque como es para adornar gabinetes, chimeneas, salones, gálerías y adorno de bóvedas, escudos de armas y cualquiera otra obra de arquitectura para iglesia como retablos, púlpitos, mausoleos y otras diferentes cosas, imitado todo perfectamente el mármol al natural, de todos géneros y de resistencia como se ejecuta en Roma, y en otras partes de Italia y aquí jamás acostumbrado. Los amadores del buen gusto, que quisieren hacer obras de este género, les hará los dibujos y pruebas que le sea mandado, haciendo en todo bastante conveniencia [23.abril.1761].

El mobiliario acomodado para el gabinete era de dimensiones más bien reducidas. Eran muy comunes las mesas, muchas de ellas doradas, también las había de piedra. Si eran de este último material por lo general se empleaba el mármol, por esta razón, aunque sea un poco posterior a los años que tratamos, merece la pena anotar un comunicado dado el 5 de enero de 1778, referido a los marmolistas: "En el taller de mármol que hay en la calle del Reloj, a la de Torija, más abajo del Pasadizo del Colegio de Doña María de Aragón, se venden adornos para chimeneas a la francesa, y tableros para mesas de salas y gabinetes, de los mejores mármoles de España, y se hace todo género de obras para iglesias, y palacios para cualquier parte y fuera de esta Corte». Además de mesas era fácil encontrar rinconeras, sillas y taburetillos - forrados de damasco o terciopelo- y arañas medianas de cristal.

La colgadura de las paredes estaba compuesta por cornucopias - siempre bastante altas-, variedad de cuadros de pequeño tamaño y repisas. Las cornucopias y repisas eran normalmente doradas y sobre estas últimas se podían disponer todo tipo de objetos, aunque lo habitual era la porcelana, llamada comúnmente china ${ }^{30}$, cosas de coral, y quizá también, ese era el lugar donde descansaban otros objetos curiosos como "un globo terrestre de metal dorado a fuego y esmaltado y una Aguja Náutica, uno y otro muy acomodados para gabinete" [9.julio.1761]; este tipo de objetos eran adecuados también para adornar las chimeneas, incluida la del gabinete si existía.

30 "La persona que quisiere comprar diferentes piezas de china blanca de la Roca vieja, o repisas para ellas y pinturas pequeñas especiales para adorno de algún gabinete, acuda a la esquina de Barrio Nuevo frente de la Merced" [29.mayo.1764]. 
En cuanto a los cuadros encontramos que había bastante variedad - razón por la cual además de la expresión cuadro se puede encontrar la de láminas, pinturas, etc. Podían tener cristales y, por lo general, el marco era dorado (medias cañas lisas). Por ejemplo, el 24 de noviembre de 1758 se daba el siguiente aviso:

En la Abaniquería que esta inmediata al Postigo de San Martín y a la calle de la Sartén, se venden láminas de distintas invenciones, muy primorosas, con marcos dorados y finos, los cuales se harán de varias invenciones, representando los santos o figuras que se encarguen; tienen dichas láminas por delante cristales para la mayor subsistencia y adorno, países de pincel, puestos sobre tabla, con marcos y cristales.

En cuanto a la pintura la adecuada era la de mediano o pequeño tamaño, podía ser sobre lienzo, tabla o cobre, y era muy frecuente la pintura sobre cristal: había especialistas del ramo y debía ser habilidad común entre los doradores. Entre la pintura de cristal que se decía propia para el adorno de gabinete se encuentran las "diferentes pinturas en cristal, retratos de reyes, emperadores" [24.abril.1758]; años más tarde se ofreció un conjunto donde figuraban fábulas con sus marcos dorados [18.marzo.1760] ${ }^{31}$; y debía ser común la variedad de tamaños y formas, según se deduce de las aláminas, pintadas al vidrio, ovaladas, cuadradas y grandes, con sus marcos y adornos de escultura todo dorado" que se ofertaron el 21 de noviembre de 1763.

En lo que se refiere a la pintura sobre lienzo, se podían adquirir juegos — sirva de ejemplo el ujuego de lienzos pintados al óleo para adorno de un gabinete con sus medias cañas doradas" que se anunció el 26 de julio de 1758- o bien obras sueltas. Sin duda, las pinturas propias de gabinete más singulares que sabemos se pusieron a la venta en estos años fueron dos "muy exquisitas de gabinete, en tablas de roble, apaisadas, que tienen tres palmos y medio de ancho y dos y medio de alto, su autor el Bosco, para su ajuste se acudirá a la calle de Toledo a la Barbería que está junto al Colegio Imperial" [6.abril y 28.mayo.1759]; y "tres pinturas de gabinete que la una es la Historia de Andrómeda y Perseo, y las otras son dos floreros que tienen una tercia de alto, bordados de seda y oro, dará razón el Ebanista de la calle de los Preciados" [16.abril.1760]. La consideración de un determinado tipo de bordado como pintura era ge-

31 El 17 de noviembre de 1764 se daba el siguiente comunicado: "En casa del ebanista que vive en la calle mayor frente de la casa del Pozo de San Isidro se venden las alajas siguientes [...] y sesenta marcos dorados de varios tamaños redondos y en ellos cristales pintadas diferentes fábulas". 
neral aunque se debe destacar la evidente diferenciación entre pinturas originales y bordadas [16.octubre.1758].

La pintura, normalmente sobre lienzo, se mezclaba con otra variedad de cuadros. Por ejemplo, se puede recoger el comunicado insertado el 27 de enero de 1759: "En el cuartel de doña María de Aragón y cuarto del Alcaide se venden con la posible equidad diferentes pinturas, buenas para un gabinete, pintadas al óleo, otras de piedra mármol bajo de relieve [bajorrelieve], todas con marcos dorados, hechos a la moda y de varios autores". Pintura en miniatura y pinturas pequeñas especiales para adorno de gabinete eran habituales: "dos pinturas de miniatura la una con la imagen de San Juan Evangelista y la otra con la imagen de nuestra señora de la Concepción, asimismo veinticuatro cuadritos con los marcos dorados y con sus cristales (vidrios de cristal) correspondientes, todos son pastorelas pintadas al óleo en tabla" [1.abril.1760] ${ }^{32}$; "cuadros en estuco dorados y con el campo negro propios para un gabinete" [26.agosto.1763]. Como se ve el estuco también podía ponerse en forma de cuadro - era corriente encontrar floreros de estuco "muy exquisitos y primorosos" entre los adornos de la pieza, hasta veinticuatro se podían llegar a disponer en una sola estancia-, y eran bastante comunes los ajuegos de floreros de Indias con marcos dorados y cristales muy decentes para cualquier gabinete" [30.septiembre.1758].

Bajo la expresión lámina cabía una gran variedad de cuadros. Se ofertaban en conjuntos a veces bastante numerosos como, por ejemplo, las doce láminas "cubiertas de cristal, con marcos de lo mismo en forma de países, que representan las cuatro partes del mundo" que se vendían junto a otros adiez ovalillos con varias figuras chinescas sobre raso liso, con bordadura de orom cubiertos de cristal y de cintas [22.agosto.1760]. La pintura en piedra era habitual. Por ejemplo el 31 de octubre de 1758 en la casa donde vivía Antonio de Fresno, situada en la calle de la Cruz frente a la casa del Conde de los Cobos, se vendían "dos pinturas países en piedra exquisitan; el 24 de mayo de 1760 en la tienda de Juan Antonio de la Iglesia que se encontraba frente al Colegio Imperial, se daba razón de un sujeto que vendía "dos floreros, que tiene una vara poco más o menos con marcos dorados y su pintura fina en piedra de jaspen; el 10 de septiembre de 1761 se ofrecían veintiséis "láminas de piedra muy exquisitas", y el 25 de septiembre de 1762 se podían adquirir "cuarenta láminas de piedra de lapis lazuli, y otras de todos colores, que figuran flo-

32 «Se venden diferentes pinturas al óleo, buenas para gabinete, y todas con marcos dorados, darán razón en el cuartel de doña María de Aragón, en el cuarto del Alcalde» [17.abril.1759]. 
res, frutas y pájaros, las dos son de a dos tercias de alto y una de ancho, ocho algo más pequeñas y las restantes de a cuartilla, obra de Florencia antigua", para su ajuste se debía acudir "a los Florentines que trabajan en casa del Intendente de la China a lo último de la calle Hortaleza, casa nueva". Entre los cuadros pintados singulares se encuentran las "veintiséis tablas de varios tamaños y de especial pintura sobre concha de nácar" [4.mayo.1764].

Hubo una especialidad que también contribuyó al adorno doméstico: la grafidia. El 1 de julio de 1758 se daba el siguiente comunicado en el Diario noticioso:

En casa de Antonio Martínez abaniquero, que vive frente del convento del Carmen Calzado asiste un sujeto que recorta en papel blanco cuanto se le pida primoroso, tanto en la exactitud del dibujo como a satisfacción del gusto mas delicado: recorta y trepa en tamaños reducidísimos, de tal modo que aun para sellos, relojes hace cuanto pueda desearse, asimismo paisajes, historias devotas o profanas, monta también abanicos de gasa adornándolos con recortados primorosos, graba asimismo en madera cuando se le pida para Marmosetos, cabeceras, viñetas y letras floridas de Imprenta. En casa de este mismo abaniquero se venden paises, pintados en Francia finos regulares y ordinarios.

Uno de los especialistas en el arte de recortar papel residente en Madrid en estos años fue Pedro Lasso de la Vega. A él se debe la Historia de don Quijote hecha para el Príncipe de Asturias don Carlos, el futuro Carlos IV, en cuyos aposentos del Palacio de la Granja la vio en 1773 Richard Twiss (Twiss 1999: 74) ${ }^{33}$.

La realidad es que el gabinete se convirtió en la pieza doméstica donde cabía todo, tanto antiguo como moderno, incluso también permitía el acoplamiento de objetos pasados de moda o viejos debidamente tratados y acondicionados. Entre ellos se destaca el abanico ${ }^{34}$. Había sujetos

33 El viajero le hizo algunos encargos al artista cuando le conoció en Málaga y por él sabemos que, cuando estaba escribiendo en Londres el libro sobre España, Lasso de la Vega residía en esa ciudad. Sobre la serie de la Historia del Quijote que se conserva actualmente en el Palacio Real de Madrid (inv. núm. 10084034-085), véase Moya VAlgañón (1997). Agradezco a María Jesús Herrero haberme facilitado esta información, pero sobre todo su amabilidad y amistad de tantos años.

34 Sobre la importancia del consumo de abanicos y la necesaria renovación de los mismos en los actos públicos véase MARTín GaITE (1981: 48 y ss). Existen otros anuncios similares en el Diario Noticioso. Por ejemplo el 4 de febrero de 1758 se comunicaba que uen el Postigo de San Martín en la Tienda de Abaniqueria que está junto a la Calle de la Sartén, hay un sujeto de industria y habilidad muy sobresaliente para componer todo género de abanicos, ya sean de nácar, marfil, hueso o madera [...] dice más en su esquela de aviso y es que pintará cuanto le pidan en este género, 
ocupados en su adaptación al nuevo uso como elemento de adorno doméstico:

El boticario de la esquina de la Cava Baja, Puerta Cerrada, dará razón de un sujeto que pinta de miniatura cuanto le pidan, de historia, santos y abanicos; y advierte que si alguna persona se hallase con abanicos de pintura fina y no los pudiere usar por muy rotos, los acomodará en tablas o cartones del tamaño que hubieran de servir, sin que se conozcan los dobleces, ni añadiduras imitando a las mismas tintas del autor, de modo que puestos con sus marcos y cristales podrán servir muy bien para adornos de gabinetes ly lo hará] de tal modo y con tanto primor que se ignore si fueron remendados o hechos de nuevo [9.marzo y $12 . \mathrm{sep}$ tiembre.1758].

Singular era la transformación a lá que se sometía a algunos muebles ${ }^{35}$. El 12 de noviembre de 1760 se hacía la siguiente propuesta: "Se venden dos escritorios, de dos varas de largo y vara y media de alto, hechos en Nápoles, cubiertos de ébano y concha, con los bronces dorados de molido, con siete cajones cada uno y cristales pintados de miniatura, que pueden servir, deshaciéndolos, para adornar un gabineten. Finalmente, entre los objetos más peregrinos que se podían anunciar para el adorno de esta

pero sin el riesgo de que se tomen o pierdan los colores. Monta los abanicos a la extranjera, dándoles mucho vuelo, aunque tenga pocas varetas y el pie chico, dejando la tela o países sin que por ninguna parte hagan arrugas». Cinco días más tarde se insertaba el siguiente: "En la calle del Horno de la Mata frente de Porta Coeli al lado de la Tienda Vidriería, en el cuarto principal, vive un sujeto de habilidad, para hacer todo género de barnices y charoles [...] compone cualquier pintura antigua, aunque esté muy rota y maltratada dejándola sana y sin que se conozca la compostura sin corromper ni destruir la fineza de la mano de su autor. Compone también todo género de abanicos, imitando los países y dibujo de Francia e Inglaterraw. El 26 de junio de 1761 se publicaba el siguiente anuncio: "En la calle Mayor portal de San Isidro, frente de un ebanista, cuarto segundo, se venden y pintan países de abanicos, y se repasan los que lo necesiten como también para poner en tabla, aparador o gabinetes \&c.n.

35 Como apunta Martín GaITE (1981: 43), en ese deseo de aparentar no tenía ya tanta importancia que "adornos, muebles y ropas fueran de buena clase y duraran mucho, para ahorrar gastos futuros, como que fueran distintos de los que les precedieron, que estuvieran al día, que parecieran bien a los demás. Se trataba, en suma, de que todo cuanto se usaba, personas u objetos, confiriera a su eventual usufructuario una aureola de modernidad. En el caso de los objetos, se diría, incluso que un designio deliberado de vida efímera presidía la fabricación de todas aquellas mercancías nuevas". La misma autora añade la siguiente cita: "Si los muebles antes eran más costosos, también era de mayor duración y, después de haber servido muchos años, se podía todavía aprovechar la materia de que se fabricasen, lo que no sucede con los papeles pintados, mesas, taburetes, canapés y otros muebles que se usan en el día", SEMPERE y GUARINOS (1788: 178). 
pieza de la casa se encuentra la oferta a "cualquier persona de buen gusto que quisiere comprar dos fuentes artificiales que pueden servir para el adorno de alguna sala, gabinete, jardín o altar, o para recrear la vista de algún enfermo para que se le quite la melancolía, pues se pueden mover con facilidad de una parte a otra, acudirá a verlas a la calle de Atocha junto a la Barbería de los Desamparados en donde Juan Rincón las manifiesta" [14.junio.1758].

Muy poca información podemos obtener del periódico referente a los adornos de cuartos. Como hemos visto, también era común emplear frisos y a ellos iba destinada la mayoría de la pintura que por su tamaño y tema no era apropiada para el gabinete. Además se deben tener presentes dos circunstancias: que la mayoría de las pinturas de tamaño mediano o grande estaban pintadas al óleo sobre lienzo, y que, por las noticias reunidas, dominaba con mucho el tema religioso, posiblemente porque éste ya no tenía fácil cabida en la galería de la nobleza ilustrada ${ }^{36}$. Sirva de ejemplo el siguiente comunicado:

Se venden cinco pinturas que representan la primera la Imagen de Jesucristo crucificado que tiene dos varas y tres cuartas de largo y vara y media de ancho, su autor el Griego; la segunda es un Niño de las Calaveras, de dos varas y tercia de alto y más de vara y media de ancho, su autor Antonio de Pereda, la tercera a Jesús, María y José, trabajando el santo en su oficio y la Virgen haciendo labor que es original de Orrente y tiene de largo vara y tercia y de ancho una tercia más, la cuarta el Sepulcro de Cristo Señor nuestro, original de Balsan — se debe referir a alguno de los Basano-, de una vara y dos tercias de largo y dos varas de ancho, y la restante un San Jerónimo de dos varas de largo y vara y tercia de ancho, daran razón en la lonja de don Juan Llaguno, que está en la esquina de las cuatro calles del Príncipe, casa nueva [19.mayo.1758].

De todas maneras existía desde luego demanda de estos asuntos porque había ya una tendencia a cubrir por completo las paredes de los cuartos con pinturas y estampas religiosas. Es interesante, aunque algunos años posterior, la descripción que William Beckford (Boyd 1954: 286) anota

36 Merece la pena recoger la descripción coetánea de una de las galerías existentes en el domicilio de doña Josefa de Zúñiga y Castro, condesa de Sarriá: "Quedé absorto al ver lo regio y espacioso de la magnífica galería, cuyas doradas rejas daban vista a los jardines. Sus grandes paredes vestían primorosas pinturas, unas mitológicas y otras simbólicas, que explicaban los géneros de la poética. A trechos, las estatuas de las musas con sus respectivas insignias, y en el testero, Apolo coronado de rayos y pulsando la dorada lira. Desde esta pieza se dejaba registrar en parte otra no menos regia que servía de biblioteca, la cual contaba con todas las obras poéticas de los españoles; siendo más y mejor lo manuscrito e inédito que lo que habían fatigado las prensas", CuETO (1893: t. I, 271), citado por MARTín Gaite (1981: 32). 
en el diario el día 10 de diciembre de 1787 sobre su habitación en casa de un veterano coronel en Santa Olalla:

El cuarto principal, donde planté mi cama, era una especie de galería con grandes puertas plegables de cristal [puertas vidrieras] doradas y barnizadas, tenía las paredes blancas cubiertas casi en su totalidad con cuadros de santos y pequeños espejos puestos cerca del techo, fuera del alcance de la vista de cualquier mortal, como si su propietario tuviera miedo a que se desgastaran por mirar en ellos. En mesas bajas, a derecha e izquierda de la puerta, descansaban vitrinas de cristal llenas de reliquias y flores artificiales. Había banquetas cubiertas con terciopelo que apenas levantaban un pie del suelo por toda la habitación. Me senté en cuclillas como un oriental en una de ellas para calentarme las manos en un brasero de carbón.

Parece que era clara la diferencia entre aquellos objetos propios para el gabinete y los que debían encontrar acomodo en el resto de la casa. Del mismo modo que existían ventas excepcionales destinadas al adorno del primero, encontramos algunos ejemplos llamativos de ventas de objetos de arte en general para el decoro doméstico. Tal es el caso del siguiente comunicado:

Quien quisiere comprar una máquina de bronce, que forma un Pedestal con un caballo y una estatua encima que representa al Rey nuestro Señor (que Dios prospere) la Máquina es obra de Soldani Toscano, y la figura de Juan Boloña, tiene en cada lado del cuadrángulo los 4 tiempos, diferentes trofeos y las armas de España; doce pedestales más chicos que representan varias historias de diferentes autores italianos; varios cuadros de Guerchino, Jorge Bazari, discípulos de Rafael de Urbino y de Antolín[ez] Español: se acudirá para tratar de ajuste a la calle de San Onofre, al cuarto segundo que está encima del zapatero catalán. Asimismo darán razón de una estatua que también está para venderse, es de mármol que representa a Hércules, cuyo autor es Piamontini [1 diciembre.1758].

De todas formas, como ocurriera con los cuadros de gabinete, hay que pensar que cuando no se emplea la palabra pintura no se trata de tal, es decir, "el cuadro muy especial" que se podía adquirir el 29 agosto 1760 no debía ser pintura, y caben todo tipo de dudas respecto a expresiones como "cuadros originales", pues lo común es hablar de pinturas originales. Entonces la palabra original tendría el sentido de cuadro curioso por su hechura; lo mismo cabe decir del adjetivo exquisito. Por ejemplo, el 23 de junio de 1759 se vendía una "pintura muy exquisita, de uno de los más afamados autores, en talla, que representa la Adoración de los Santos Reyes", propia tanto para un oratorio como para una sala. Caso similar debe ser el cuadro primoroso de una tal María Roldán que tenía para su venta el prendero de la puerta de los Consejos el 10 de junio de 1758, 
representaba "la venida de Nuestra Señora (acompañada de santos, ángeles) a poner la Casulla a San Ildefonso, Arzobispo de Toledon; si, como suponemos, era obra atribuida a Luisa Roldán, entonces se trataría de un cuadro escultórico.

Entre la información que se añadía sobre las pinturas se podía dar el tema y las medidas pero no decir el autor ${ }^{37}$, indicar tan solo que eran "pinturas originales de los mejores autores", o de autores célebres, o aclarar que eran copias ${ }^{38}$, advirtiendo si eran buenas; igualmente las pinturas podían ser nuevas o antiguas, finas, de gusto, de buena mano, de varios autores o, simplemente, de distintos tamaños ${ }^{39}$.

Entre la pintura anónima debemos suponer que había obras contemporáneas, principalmente aquellas que se decía adecuadas para el gabinete, pero resulta imposible evaluar en qué proporción con respecto a las antiguas. Es muy posible que se encontraran entre las calificadas como pinturas originales de gusto o pinturas finas. Sabemos que eran contemporáneos los retratos de los reyes que se vendían el 23 de diciembre de 1758 y el de Carlos III que se ofreció años más tarde [22.octubre.1764]. En las referencias a la pintura antigua sí aparecen nombres concretos. Destacan por su número las que dicen ser de mano de Ribera y Tiziano, y a estos autores hay que añadir: Francisco Rici, Luis de Morales, Diego Velázquez, Bartolomé Murillo, Lucas Jordán, Salvatore Rosa, Van Dyck, Alberto Durero, Rafael, Mateo Cerezo, El Bosco, Antonio de Pereda, Pedro Orrente, etc. En ocasiones se da el nombre sin que a ciencia cierta se pueda decir a quien se refiere, tal es el caso del conocido como Ticianelo ${ }^{40}$, y hay casos en los que se da un nombre parecido como el

37 "La persona que quisiere comprar una pintura original muy antigua que representa el Descendimiento de la Cruz de dos tercias en cuadro, acuda para su ajuste a la calle de San Jacinto, casa núm. 10 cuarto segundon [24.julio.1765].

38 "Quien quisiere comprar escritorios y varios escaparates o algunas pinturas que no son originales, acuda a la casa bodega frente de la Fuente de San Antonio de los Portugueses que se darán con conveniencia" [2 abril 1766]; "Quien quisiere comprar varios escritorios, escaparates y pinturas buenas aunque no originales acuda al cuarto bajo de la bodega en la corredera de San Pablo que se dará con equidad" [13.abril.1767].

39 „En la calle de Jesús y María entrando por la Portería de la Merced en el portal que está antes de llegar a un maestro tejedor de lienzos en un cuarto bajo se venden algunas pinturas de distintos tamaños y todas originales de varios autores" [17.mayo.1758].

40 "La persona que quisiere comprar una cama imperial, colgada de damasco carmesí, una alfombra de seis varas de largo y cuatro y cuarta de ancho, seis pinturas de siete cuartas de ancho y seis de alto su autor el Ticianelo, acuda para su ajuste a la prendería que está en la calle Fuencarral frente de la capilla de nuestra señora de la Soledad" [7.marzo.1765]. 
de Antolino, que probablemente se refiera a Antolínez, del cual había a la venta una pintura original que representaba la Adoración de los Reyes [28.diciembre.1758].

La cuestión de la autoría es interesante. Los editores del periódico tenían cierta cautela a la hora de dar nombres de pintores, en más de una ocasión matizan la cuestión con expresiones como "dicen ser" o "que dice son originales den. En este sentido, entre los comunicados curiosos se encuentra el siguiente:

En la calle de Silva, frente de la Buena Dicha en la tienda del ebanista darán razón de un sujeto que vende tres pinturas, que dice son originales, de dos varas y algo más de ancho, y una y media de alto, adornadas con marcos de talla dorados. Las dos son perspectivas del Bibbiani, dice la esquela; pero se engaña porque no hay sino Fernando Galli conocido con el sobrenombre de Bibiena, natural de Bolonia y gran pincel para representar con excelencia todo género de perspectivas: de este célebre autor dice son las dos perspectivas; la una representa el campo Bachino de Roma y la otra el Arco de Constantino. La tercera es del Bassan en la que se representa el sacrificio de Noé, cuando salió de la Arca después del Diluvio, se darán con mucha equidad [11.agosto.1758].

El caso más singular está relacionado con Murillo. El 11 de julio de 1761 se daba el siguiente aviso: "En la calle del Olivo esquina a la de Jacometrezo, cuarto principal encima de una Taberna se venden doce pinturas juego entero apaisadas, que tiene de ancho dos varas y de alto vara y tercia, Historia de la Virgen Santísima, su autor el Maestro Tobar, compañero de Murillo, pintor que fue de Cámara del Señor D. Felipe V (que Dios goce)". Cuarenta y dos días más tarde esa información se ve sustancialmente transformada: "La persona que quisiere comprar doce pinturas apaisadas que contienen la Historia de María Santísima, con sus marcos dorados, burilados de filigrana, que se han conducido de fuera de la Corte, las cuales tiene de ancho dos varas y de alto vara y tercia hechas (que se dice) por mano del Maestro Murillo, acuda para tratar de ajusten. No debió ser fácil vender la serie, o el efímero propietario decidió deshacerse de ellas pronto, pues el 8 de febrero de 1765 el campanero de la iglesia de Santa Cruz, Juan Martínez, las enseñaba a quien se interesara por ellas en la sala de la Sacramental de la misma junto a otro cuadro de la Magdalena de Mateo Cerezo de cinco cuartas de ancho y una vara de alto. No es posible saber si las pinturas de Murillo que se ofertaban el 10 de febrero de 1766 - de las cuales daban razón en la casa del espartero que se encontraba en la calle de Fuencarral esquina a la de Santa Bárbara la Vieja- eran las mismas, ya que sólo menciona que tiene de venta pinturas del autor sevillano y del Españoleto además de cornucopias a la moda, alfombras, un guardarropa de nogal a la moda de Inglaterra, etc. 
Cuestión aparte debemos hacer de las copias. "Excelente", "bella", "bellísima", "muy buena", "exactísima y acabada" copia, o "copias razonablemente ejecutadas", "copias razonables y dignas de estimarse", "no es mala copia", etc., son las expresiones con las que Antonio Ponz va salpicando su descripción en el primer tomo de su Viaje de España publicado en 1772. Hay que tener presente que la calidad y fama de una pintura se acrecentaba por el número de copias que de ella se habían sacado y, una vez más, nos encontramos con Tiziano: la Adoración de los Reyes en medianas figuras y el Santo Entierro en figuras algo mayores que describe Ponz en la iglesia vieja del Escorial eran, en su opinión "obras maravillosas, y conocidas por las muchas copias que de ella se ven, y por las repeticiones, que el mismo Tiziano su autor hizo particularmente del Sepulcro" (Ponz 1773: II, 143-144) ${ }^{41}$.

Hay que recordar que copiar pintura no era un descrédito para los profesores, en consecuencia hay que pensar que algunas de las copias que se pusieron a la venta en estos años eran contemporáneas. El mismo Ponz no sólo recuerda que es una manera adecuada para aprender, sino también que copiar a los maestros "no lo han tenido a menos valer, otros que lo han sido de gran reputación en la pintura; y en tal caso sus copias se han estimado, y deben estimar en tanto, o más que otras pinturas, bien que originales, y de autores conocidos. En España no falta, como dije arriba, buenas copias de las más singulares obras de Rafael, Miguel Angel, Leonardo de Vinci, Correggio, y otros eminentísimos hombres en el arte" (Ponz 1772: I, 151-152) Por estos mismo motivos era lógico que entre los méritos de un pintor Ponz apreciara su capacidad para copiar pinturas, tal es el caso de Lucas Jordán (Ponz 1772: I, 333 y ss). El autor llega incluso a poner en duda que algunas de las pinturas tomadas por copias de él fueran en realidad de su mano (Ponz 1772: II, 120).

No es posible saber cómo se determinaba al insertar el aviso en el Diario de Madrid si se trataba de una copia o no. No debe extrañar que en el mismo comunicado se hable de originales y copias porque resulta evidente que se encontraban mezcladas y, en algunos casos, se valoraban más las copias que las pinturas originales, del mismo modo que era digno de crédito el coleccionar copias de calidad de buenos originales. La capacidad de diferenciar una copia de un original era valorada desde antiguo y por consiguiente en esta época, como en las anteriores, había curiosidad "en indagar si hay regla segura, y cierta para conocer perfectamente si una pintura es original, o copian, curiosidad considerada por Ponz

${ }^{41}$ Huelga decir que la colección del Escorial fue fuente inagotable de copias de las que da cumplida noticia el autor. 
"Común a los aficionados, que verdaderamente aman la noble arte de la Pintura; y asimismo lo es el deseo de saber cual sea esta reglan. Se aventura el autor en mar tan proceloso con cautela (se ocupa por extenso en Ponz 1772: I, 333-342), advirtiendo que puede haber engaño casi desde el momento mismo en el que se concibió la pintura al dejar el maestro en manos de discípulos copiar sus originales y luego retocarlas para su venta como originales. Duda Ponz que puedan ser apreciadas como tal, por el contrario considera que existen copias no menos bellas que los originales porque "tal vez se halla dentro un cierto no se qué de mayor precio" que en ocasiones haría dificultoso saber que son copias "si no supieramos de los originales" ${ }^{42}$.

Entre las noticias que nos suministra el periódico se puede apreciar la presencia de copias, incluso de los maestros citados por el mismo Ponz. Uno de los artistas españoles más copiados fue Ribera, por eso no extraña que también se pusiera a la venta alguna copia suya, como por ejemplo la Purísima Concepción que se ofertaba en la prendería de la calle Fuencarral el 28 de diciembre de 1758. El resto de las pinturas de Ribera se consideraron originales ${ }^{43} \mathrm{y}$, como era de esperar, todas tratan asuntos religiosos. Entre las pinturas sueltas se encuentra la que pusieron a la venta los herederos de Miguel Arizcun ${ }^{44}$, un san Antonio de dos varas y media de largo y dos de ancho - daban razón en la plazuela de la Cebada, en la cofrería [22.febrero.1758] - que hacía pareja con una pintura anónima que representaba a san Miguel [8.marzo.1758]. Más interesantes resultan las "cuatro pinturas del Españoleto con los cuatro evangelistas, san Juan, san Lucas, san Marcos y san Mateo" [21.marzo.1760] y las "diversas pinturas originales, hechas por mano de Ribera, en varios cuadros en que se incluyen doce, que son las tribus de Judá, cuatro Historias de David, diez de filósofos" [22.agosto.1760]. En un anuncio del mes siguiente se precisa además que uno es "de la Virgen con san José y el Niño Dios de cuatro

42 Indudablemente hay que tener presente que Ponz fue el editor del libro de Felipe DE Guevara, Comentarios de la pintura (Madrid, 1788). El tema ha sido estudiado por PORTÚs (1997).

43 "Si alguna persona quisiere comprar tres pinturas de la mano de Ribera acuda a la calle del Olvido Alto, a la casa inmediata a una Barbería cuarto bajo" [11.febrero.1758].

44 Miguel de Arizcun, primer Marqués de Iturbieta, era, en palabras de Julio Caro Baroja, un solterón muy piadoso, y dejó dos mayorazgos, el primero de ellos a Francisco de Arizcun, pagador general de juros y mercedes en Madrid. La familia Arizcun, de origen navarro, pasó "de la vida, más o menos entonada de unos campesinos baztaneses a la fastuosa del potentado de la Corte" en dos generaciones; véase CARO BAROJA (1985: capítulo IX). 
varas y tres cuartas de ancho y diez de largon. A las citadas hay que añadir la mencionada anteriormente de Caín y Abel que se vendía en casa de Juan Rubio junto a otra pintura de Tiziano. De este pintor daban razón de un retrato de Antonio Pérez de vara y media de alto con su media caña dorada en la carpintería de la calle del Duque de Alba ${ }^{45}$; un EcceHomo de medio cuerpo tasado en cien doblones [16.marzo.1758]; dos retratos en tabla que se pusieron a la venta junto a la pintura "original de un famoso autor" de la Adoración de los Santos Reyes el 18 de julio de 1758; y cuatro cabezas de apóstoles "con marcos de metal abiertos a cincel y dorados de molido para su ajuste se acudirá a casa de Miguel Lores, maestro dorador de mate, calle de las Carretas inmediato a la Botilleria" [13.enero.1762].

Surgen dudas y equívocos al leer el Diario, principalmente porque se encuentra dificultad para diferenciar entre estampas y pinturas sobre cobre. Algunos casos son claros, por ejemplo la oferta que se dio el 28 de febrero de 1758: "en la calle de Alcalá, casa que hace esquina a la de Cedaceros, cuarto principal, se venden doce láminas romanas de cobre de diferentes santos con los marcos de cristal con varios sobrepuestos de bronce, todos uniformes, asimismo doce pinturas en lienzo de más de vara de alto con marcos dorados, que significan las doce naciones de la Nueva España". Mayor dificultad hay para saber qué tipo de obra era "la lámina de cobre con la imagen de San Ignacio que tiene una vara de alto y tres cuartas escasas de ancho", original de Tiziano que se vendía en la calle de la Abada frente al Molino de chocolate, aunque nos inclinamos por pensar que se trata de una estampa calcográfica de importación, y lo mismo ocurre con las "pinturas de humo con los marcos dorados" que se vendían el 9 de febrero de 1760; debían ser pinturas grabadas al humo, estampas de importación, verdadera rareza en el Madrid de la época.

El cuadro original de un famoso autor con la Adoración de los Reyes Magos que se vendía junto a una pintura de Tiziano, era una tabla de Alberto Durero, según aclaración del 1 de diciembre de 1758, hecha "propiamente para un oratorio portátil». No es raro que aquellas obras que en un principio figuran sin nombre, pronto aparezcan con el de algún pintor conocido. Tal es el caso de la Concepción de tres varas de largo y el ancho correspondiente que también se ofrecía sin autor junto al Durero, y que en el anuncio del 10 de abril de 1760 se dice que es de Corezo - probablemente Mateo Cerezo aunque podría también pensarse en Correggio si se tratase de pintura extranjera-, se ofertaba con un cuadro de la escuela de Rafael. En la pintura rafaelesca se veía "la imagen de

45 Se vendía junto a un original de Morales y otro de Velázquez [1.marzo.1758]. 
Nuestra Señora y el niño Dios en los brazos y a un lado esta san Josén, haciendo la indicación de ser "muy buena para una cabecera de cama"; el 22 de diciembre de 1761 se decía ser copia de una obra del maestro de Urbino.

El 7 de mayo de 1762 el cuadro de Durero todavía no se había vendido. Pero por las noticias reunidas parece que el sujeto se dedicaba principalmente al comercio de objetos artísticos y debía ser bastante conocido en la ciudad entre los interesados por estas mercancías pues daban razón de él tanto en la Imprenta del Diario, como en la Barbería que había junto a la imprenta, en la vidriería de la calle Hortaleza, esquina a la de las Infantas, y en la tienda de aceite y vinagre que estaba en la calle del Clavel, esquina a la plazuela del convento de los Capuchinos de la Paciencia ${ }^{46}$. Además del Durero y la copia de Rafael, vendía "un juego de 28 pinturas pastoriles y venatorias, originales de Salvador Rosi [Salvatore Rosa], de diferentes tamaños dignas de ocupar una casa de campo o la galería de un príncipe [...] dos retratos, uno del Rey don Juan $\mathrm{V}$ de Portugal y el otro de la reina Doña Mariana de Austria, su mujer, hechos de tapiz muy delicadamente", cinco "tapices de diferentes tamaños buenos para entrepuertas o para una alcoba", un abanico muy exquisito de nácar con figura embutidas de oro, un brial de tapiz, veintiséis láminas de países en piedra, etc.

Como se ve el Diario Noticioso vino a cubrir, desde luego, una necesidad de difundir y comunicar la mercancía de objetos de arte, pero también vino a cumplir otras funciones como la de publicitar los robos. Del mismo modo que parece evidente la existencia de un mercado, y por consiguiente de una demanda, es lógico pensar que había expolios. La complejidad que en ocasiones se encuentra en el sistema de referencias se debe en gran medida al confuso sistema de numeración de inmuebles que existía en Madrid en aquella época ${ }^{47}$, pero también cabe pensar que se hacía con la intención de filtrar a los posibles interesados. Es decir, en muchas ocasiones se llegaba a un lugar donde daban razón del objeto publicitado, no al local o vivienda donde se encontraba físicamente el objeto; sirva de ejemplo el siguiente comunicado: “En la calle de Valverde,

46 [1.diciembre.1758; 18.febrero.1760; 10.abril.1760; 28.octubre.1760; 18.julio.1761; 10.septiembre.1761; 22.diciembre.1761; 26.abril.1762; 7.mayo.1762].

47 Un caso singular de esta complejidad es la tienda de perfumes y licores donde puso a la venta Francisco de Goya la primera edición de Los Caprichos. Se encontraba situada en el número 1 de la calle Desengaño, pero resulta que en ese momento había cinco casas con el mismo número en aquella calle. Véase GLENDINNING (1996: 52-53). 
antes de llegar al oratorio y frente de un ebanista junto al Estanco Real del Aguardiente vive Pedro Picart quien dará razón del sujeto que tiene de venta varias pinturas de los mejores pintores que se han conocido todas originales y se darán con equidad al comprador" [7.julio.1761].

Se dieron noticia tanto de robos antiguos como contemporáneos. El 6 de septiembre de 1758 se encuentra el siguiente comunicado:

El día 24 de julio de 1750 se desaparecieron de una casa las alhajas siguientes: 2 cuadros flamencos, pintados sobre tabla, que representan un baile, o fiesta de paisanos que ambos tiene de largo cuarta y media y una de ancho, con la moldura de media caña dorada; otro igual de una Concepción del célebre autor Murillo, con su moldura labrada y dorada; otra de media cuarta con su moldura de color de café y dorado pintado un san Jerónimo sobre tabla con vidrio; otro en cobre, con una Nuestra Señora de la Soledad, de medio cuerpo y de media cuarta en cuadro, con su moldura negra y algunas otras cosas, para la restitución se acudirá a casa del ballestero de Su Majestad que vive en la calle de Fuencarral, en el cuarto principal, que está encima de la Prendería y frente del Herrador, quien dará lo que hubiere costado, o la gratificación correspondiente.

El 31 de mayo de 1759 se daba noticia de un robo coetáneo: "En los días de la Semana Santa se desapareció de una casa el Retrato de una religiosa Agustina sentada en una silla, y asimismo dos cubiertas de mesa de badanan. El 19 de noviembre de 1762 se daba el siguiente comunicado a los que hubieran adquirido mercancía robada de buena fe o, quizás, a los que habían robado pensando en el rescate: "La persona que tuviere noticia de doce láminas de cerca de media vara de largo y una tercia de ancho, las dos de ellas (que forman cabecera de medio punto) son mayores, pintura romana en cristal con marco de concha y molduras de ébano que han hurtado en su casa al señor José de Molina y Sandoval que vive en la plazuela del Conde de Moriana en el cuarto bajo del Sr. Conde de la Villanueva, se darán a quien diese razón de donde para u las entregare 200 reales de gratificación. Igualmente se podía dar noticia de las pérdidas, por ejemplo la siguiente: "el día 7 de este presente mes se perdió una pintura en lienzo que representa un frutero con su bastidor que tiene de alto más de media vara y lo correspondiente de ancho desde la villa de Valdemoro hasta el Real Sitio de Aranjuez, para su restitución se acudirá al nominado sitio al cuarto del serenísimo señor infante D. Luis y en esta Corte a la real casa de la Chinan [9.mayo.1765].

Siguiendo con la nómina de pintores, del célebre Murillo no se ofertaron muchas pinturas además de las ya mencionadas. Como original del pintor se daba el cuadro que vendía Santiago Casale - comerciante que vive en la plazuela del Angel inmediato al Oratorio de San Felipe Neri, casa nuevan-, una pintura de la Virgen con el Niño de cerca de dos varas y 
media de alto y vara y tercia de ancho [9.enero.1762]; y en la "calle de las Hileras cuarto principal, junto a un cerrajero donde vive Don Antonio Casanova se venden tres pinturas originales, la una en cuadro grande de Morillo [sic]" con marco [18.octubre.1758].

Otro autor de prestigio en aquella época era Lucas Jordán y de su mano se dan mayor variedad de pinturas. La primera asociada a su nombre que encontramos era la que se mostraba en la calle del Candil esquina a Preciados, encima de una tienda en el cuarto principal, que tenía un tamaño de dos varas y medio de alto y vara y media de ancho, y representaba a la Sagrada Familia en cinco figuras [17 marzo y 14 agosto, 1758]; en el comunicado de 23 de noviembre de 1758 además se podían comprar "unas tablas sacras destinadas para altar"; todavía se encontraban todas a la venta el 22 de febrero del año siguiente. El 25 de abril de 1758 en la librería de Bartolomé López, situada en la plazuela de Santo Domingo, se vendían dos pinturas originales de cuatro varas y media de alto y lo mismo de ancho cuyo tema era de historia sagrada. Entre las cuatro pinturas de diferentes tamaños de cuyo paradero daba razón el portero del Ministro de Suecia cuyo domicilio era cercano al Convento de Mercedarios Descalzos de Santa Bárbara, "dos son de Jordán [así lo dice la esquela de aviso], una de José Moreno, y la otra de un autor italiano" [5.junio.1758]; de un cuadro con la imagen de la Virgen de la Leche daba razón la mujer que vendía verdura en la puerta del Cuartel de Inválidos de la plazuela de Santo Domingo -esta última también tenía para vender un cuadro original de la mujer adultera [27.junio.1759]. No sabemos el tema de las que se ofrecieron el 11 de febrero de 1760 de las cuales daban razón en la carpintería de la calle Hortaleza inmediata a la carbonería, aunque quien las tenía a la venta era el dorador que vivía en el cuarto segundo de la casa nueva, situada frente a una cruz de la calle San Pedro y San Pablo, una de ellas era de dos varas de alto y lo correspondiente de ancho (además contaba con otras pinturas). Finalmente merece la pena destacar dos ofertas que salieron en el Diario. La primera data del 29 de enero 1760 y dice así:

Se vende una Pintura, hecha por mano de Jordán que tiene dos varas de alto y representa la Escalera del Escorial, asimismo una docena de platos pintados con dibujos de Rafael, una asta de unicornio, una espada moruna [...] un biombo que tiene ocho hojas y de buena pintura, cinco niños de Nápoles y entre ellos un Niño de Pasión, una pintura que representa la Imagen de San Genaro, su autor el Españoleto, otra pintura con la imagen de nuestra señora de Guadalupe de México y otras diferentes, para su ajuste se acudirá a casa de Francisco Leyraud, que vive en la calle del Estudio, frente a la casa del Señor Vicario. 
La última es de 27 de agosto de 1760: "En la calle del Barco, entrando por la del Desengaño, a la segunda puerta de mano izquierda, casa pintada, cuarto principal se venden seis floreros hermanos con sus cañas de moda, juntamente con una Magdalena, de cuerpo entero que se cree ser de Jordán. Los Floreros son de Arellano".

Además en estos años se pusieron a la venta obras de los siguientes pintores españoles: de Francisco Rici una Asunción y una Concepción de 9 pies de largo y 6 de ancho, original [20. febrero y 27.julio.1758 respectivamente]; de Velázquez un bufón llamado Juan Rana [1.marzo.1758]; de Morales al citado anteriormente se suma una Concepción [9.febrero.1760]; de Mateo Cerezo además de la Magdalena y la Concepción mencionadas, se ofreció, sin explicación sobre el tema, alguna pintura el 7 de marzo de 1759, dos años más tarde [30.octubre.1761] se informaba que estaban de venta "dos cuadros, iguales el uno con la Imagen de San Francisco y el otro con la de Santo Domingo, originales"; del "afamado sevillano" el racionero Cano, se vendían dos uáminas pequeñas, pintura fina en cobre original" una de ellas "la Sacra familia de mi Señora Santa Ana y la otra del Glorioso San Antonio de Padua" [7.octubre y 3.diciembre.1760]; finalmente, entre los diferentes juegos de pintura que tenía encargado vender el escribano de número Leandro Beleña se encontraba la Historia Sagrada de Antonio Palomino [23.junio.1761].

Como se ha podido ver, era escasa la pintura que se ofertaba de tema no religioso. Esta circunstancia era de esperar; la mayor parte de la pintura que había en España en aquel momento era religiosa. Por esta misma razón cabe observar que en la pintura de Goya los temas que se pueden reconocer en los cuadros son diferentes, se trata de un retrato y una cacería. Sobre retratos ya hemos visto alguna breve referencia, pero siempre se trata de personajes importantes como los reyes. El retrato no era tema que atrajera la atención aunque es evidente que los habría. Tener retratos ajenos era menos ambicioso que hacerse retratar: basta dar un repaso a la pintura española de la segunda mitad del siglo XVIII para apreciar la creciente demanda de este tipo de servicios, al fin y al cabo así se emulaba a esos personajes influyentes. Entonces, es fácil entender el siguiente anuncio que se insertó en el Diario del 14 de octubre de 1762:

En la Corredera de San Pablo, frente de la de San José cuarto principal vive un sujeto, pintor, recién venido a esta Corte, que tiene habilidad para retratar al óleo, siendo de hombre de medio cuerpo del natural, con manos y no siendo el vestido muy cargado de bordados, por el ínfimo precio de cinco doblones, advirtiendo que, no estando parecido, no llevará interés, y siendo de mujer, y en sus casas, a proporción del trabajo que se aumentase. 
Entre las ofertas de pinturas que se daban en el Diario sí hay referencias a vistas, perspectivas, países, marinas y bodegones. Como pintura de perspectivas, se presentaban las dos que mostraban la Historia y Templo de Salomón, pues se valora en ellas su "arrogante arquitectura y con marcos modernos corleados" de "dos varas y medias de largo y vara y tres cuartas de alto cada una" [31.agosto.1758]; se puede pensar que eran pinturas los "catorce cuadros de perspectiva con sus marcos corleados, los diez son las diez plazas principales de Roma y los cuatro países de bosque" [14.julio.1763]; dos países con marcos dorados se ofrecían el 23 de junio de 1759; un juego de países en tabla el 9 de diciembre de 1761; ocho países con marcos dorados y cristales el 9 de diciembre de 1765; y otros seis países con marcos dorados el 14 de marzo de 1768. Las únicas pinturas de este género que merecieron ir acompañadas del nombre del autor fueron las cuatro marinas, de especial perspectiva, del famoso flamenco Grossens, que podían ser adquiridas junto a múltiples enseres de la casa a partir del 14 de julio de 1761.

No es mayor el número de noticias que tenemos de bodegones. Cuatro pinturas que se componían de ufrutas, flores y ropas apaisadas, y que tiene dos varas de largo cada una y vara y media de alto" se ofertaron el 19 de octubre de 1762; y en un comunicado de varias pinturas originales que se dio el 19 de abril de 1766 se encontraban seis bodegoncillos y seis floreros junto a diversas referentes a la Virgen, algunos santos y la Historia de Betsabé. En este género habría que añadir los ya citados floreros de Arellano.

El tema religioso, tan presente en las ofertas de pintura española, era menos frecuente en la pintura extranjera. Entre los comunicados de venta de estas últimas se puede citar el siguiente del 18 de abril de 1758: "Se venden dos pinturas en tablas, originales de Antonio Ban Deick, la una de siete cuartas de largo y tres de alto, que contiene una fiesta bacanal, y la otra un Convite de los Dioses, de tres cuartas y media de largo, y tres de alto. Asimismo un florero de lienzo con dos niños que sostienen las flores, original de Pablo Mathei, daran razón en la plaza mayor encima del Peso Real al cuarto principal. Ese mismo día Jacinto Martín de la Fuente, batidor de oro, que vivía en la calle de Majaderitos, entrando por la de las Carretas, primera puerta a la derecha, tenía para vender "siete retratos de la Real familia de Francia, de tres cuartas en cuadro, con marcos dorados de moda, cuyas pinturas son especiales y se daran con bastante equidad juntamente con otros originales de Van Deick".

Rafael era otro de los maestros al que se hace referencia. Junto a dos pinturas originales "figurando países" se vendía una "pintura grande en lámina, su autor Rafael de Urbina, tasada en 18.000 rs" sin decir el tema 
[23.noviembre.1758]. Poco después se ofrecía una pintura antigua sobre lienzo "de una vara de largo y dos tercia de ancho, que representa la Historia de la Galatea con cinco figuras pintadas" [2.diciembre.1758]; y a éstas se suma una pintura original en tabla, de vara y media de largo y una vara poco más o menos de ancho, apaisada, que representaba la Cena del Rey Baltasar, que se vendía junto a otra en el mismo tipo de soporte, forma y tamaño que representaba el Triunfo de David "hecha por mano de Michael Angelo" [24.enero.1760]. Como "Escuela de Rafael" se dio otra pintura en tabla de una vara de alto y tres cuartas de ancho con una imagen de San Juan Bautista [1.marzo.1760]; y como copia de un original del pintor un san José [22.diciembre.1761].

De Francesco Solimena se ofertaron "cuatro pinturas napolitanas" que representaban: "la primera a santa Teresa, la segunda san Miguel, la tercera san Francisco de Asís, y la cuarta la Concepción de nuestra Señora, se acudirá a la casa de la Escultura que esta en la plazuela de Rebeque, junto al Pretil del Real Palacio Nuevo, en donde vive Don Antonio Martín" [25.noviembre.1758]. Sin señalar el autor se ofertaron "varias pinturas del rey de Prusia que está puesto en Batalla con todo su ejército contra Daun y otras distintas de otros reyes que ha habido en Inglaterra, acuda para tratar de ajuste a la Barbería que está en la calle de Atocha frente a nuestra Señora de Loreto y junto a una Prendería las que se darán con equidad" [5.octubre.1761]. El 4 de julio de 1768 "en la calle del Olmo, entrando por la de Santa Isabel, a mano izquierda, casa núm. 14, cuarto segundo, se vende una colección completa de doce pinturas seis de hombre y seis de mujer de anatomía de un célebre autor Inglés: es lo mejor que hasta ahora se ha trabajado en el asunto y muy digno de colocarse en el estudio de un sujeto curioso", las acompañaba "un librito impreso en lengua latina en que explica muy por menor todas las partes del cuerpo humano" [8.julio.1768]. Finalmente, también eran pinturas hechas en el extranjero aquellas de las que se daba razón en la librería de Francisco del Castillo, ubicada en la calle del Correo: "un cuadro, con una imagen hecha en Roma, de lo más exquisito que se ha visto con marco dorado, y tallado y su cristal delante" [14.julio.1760] y "un cuadro con la imagen de San Pascual Bailón, hecho en Nápoles con su cristal y marco dorado y tallado" [17.julio.1760].

Sobre los puntos de venta y los encargados de llevarlas a efecto la información que se puede obtener es en cierto modo confusa. Parece que cualquier tienda, establecimiento o taller era bueno para vender o dar cuenta de un sujeto que tenía algo que ofrecer; destacan no obstante las barberías. Si se retrasaba la venta, el sujeto encargado del negocio iba ampliando el número de establecimientos donde daban noticia de ella. 
Comentábamos anteriormente que había algunos sujetos que parecían estar especializados en la venta de objetos de arte, también cabe pensar que existían domicilios particulares donde se acumulaban este tipo de mercancías, sin que se pueda precisar si era una actividad estable o eventual. Singular era, sin duda, el localizado en la "plazuela de Trujillo, casa que hace esquina a el revolver al Convento de San Martín que los balcones caen frente de la casa de Santa Teresa". Allí se pusieron en venta:

\begin{abstract}
una Imagen de nuestra Señora de la Concepción con su trono, la peana tallada y dorada con su corona de plata guarnecida de piedras; dos lámparas de filigrana de plata que tiene vara y media de alto con la peana, varios adornos de plata y ángeles, en una urna de palo santo guarnecida de bronce y de cristales; seis láminas muy exquisitas que tienen una vara de alto y vara y tercia de ancho, historia de la Pasión de nuestro Señor Jesu-Christo; tres pinturas una de San Agustín, otra de San Jerónimo y otra de San Antonio, que tiene de alto tres varas, y dos y media de ancho con marcos azules, sobrepuestos de talla dorados; otra de perspectiva de ruinas de dos varas y media de largo con el marco dado de azul; otra de San Antón Abad de vara y media de alto con marco negro sobrepuesto de talla dorada; otra de un Santísimo Cristo con la Cruz a cuestas en tabla, que tiene dos tercias de alto y media vara de ancho; catorce floreros de muy buen gusto; un baño de cobre grande con los pies de bronce; dos tinajas de china [...] dos papeleras de Alemania embutidas de diferentes maderas que forman diversos países, figuras y cacerías con pies de talla; diez mapas con sus medias cañas para envolverse y algunos otros trastos de menor estimación [2.mayo.1759].
\end{abstract}

En un comunicado de 17 de abril de 1760 seguían a la venta las pinturas de san Jerónimo y de san Antonio, pero además había "otra con la imagen de Nuestra Señora que tiene vara y media de ancho y una de alto con su media caña dorada, otras dos iguales, el robo de Helena la una y la otra de Venus y Marte con medias cañas doradas, otra con la imagen de San Agustín original de Claudio Coello que tiene vara y media de lado y dos de ancho, con el marco azul y talla dorada y otras muchas, cuatro retratos diferentes, una urna grande de concha y ébano guarnecida de bronce, con nueve cristales el uno de ellos tiene más de una vara con su repisa tallada y dorada".

Ensambladores, carpinteros, ebanistas, batidores de oro y doradores eran también habituales entre los que mercaban con objetos de arte. El dorador que vivía en el cuarto segundo de la casa nueva, situada frente a una cruz de la calle San Pedro y San Pablo, contaba con pinturas "muy buenas de diferentes autores" para vender [29.abril.1760]; ya hemos visto que el maestro dorador Miguel Lores estaba en el negocio, e igualmente el que vivía en la calle de Alcalá frente al buen Suceso vendía pinturas de Tiziano, etc. Realmente, entre los individuos dedicados al comercio de obras de arte, los doradores ocupaban un lugar relativamente importante. La razón 
principal era la misma actividad que desarrollaban: el gusto por el dorado de marcos, esculturas, muebles y objetos diversos estaba muy extendido. Entre los doradores que comerciaban con objetos de arte en su casa se encontraban incluso los que estaban al servicio del rey; sirva de ejemplo el que vivía en la calle del Colmillo [4.marzo.1758]. Otros doradores que vendían pinturas eran: el que estaba establecido en la Carrera de San Francisco, tenía el 12 de junio de 1758 una Concepción de "dos varas y media de alto con el ancho correspondiente y marco tallado y dorado de modan; el que vivía en la calle de la Abada, frente de Retamar entre un zapatero de nuevo y otro de viejo, que tenía una "pintura, lámina de cobre, de dos tercias en cuadro, que representa a nuestro Señor Jesucristo difunto en manos de un Angel que está en acción de ponerle en el Sepulcro, a María Santísima nuestra Señora y a San Juan, su autor el divino Morales" [29.noviembre.1758]; el de la calle de la Cruz que tenía "un cuadro original con la imagen de Santa Teresa de Jesús" [15.febrero.1762]; y el de la calle Silva, frente a la cocheras del Marqués de Castelar, donde se podían encontrar «algunas pinturas buenas, espejos, mesas, cornucopias, y otros muebles" [2.enero.1778]. Sabemos, además, que en la plazuela del Ángel frente a la botica y junto a San Felipe Neri vivía otro dorador que comerciaba con escultura [27.abril.1758], actividad que desarrollaban también Francisco Alapuente, dorador domiciliado en la calle de la Manzana [18.mayo.1758], el dorador que vivía en la casa del Pez, en la calle del mismo nombre [21.noviembre.1760], el que vivía en la calle ancha de San Bernardo, frente al Noviciado de la Compañía de Jesús [9.mayo.1761]. Solían ocupar los cuartos bajos, por lo que cabe suponer que tenían tienda, aunque esa expresión sólo se encuentra en el comunicado insertado el 17 de febrero de 1761 — "calle de Toledo, frente de la casa del Señor Conde Humanes, junto a la Cerería de Terán 1765 - calle de la Magdalena, frente de la casa que llaman de la Bulera".

La venta era también actividad propia de pintores. Entre los ejemplos que se conocen ${ }^{48}$ se puede citar el siguiente: "Se ha traído a esta Corte para vender una pintura antigua, original de las más excelentes que hizo el autor, representa el martirio de San Lorenzo, historiado con varias figuras, su grandor es cuatro varas de alto y tres de ancho, se hallará en casa de Don Vicente Sánchez Pintor que vive frente de las monjas de

48 "En mitad de la calle de la Ruda entrando por la Plazuela de la Cebada en casa de un Pintor que vive en un cuarto segundo [no hay otras señas] se vende un cuadro, en que se representan la Imagen de Jesucristo en el acto de coronarle de espinas es apaisado y de dos varas, pero muy especial y se dará con grande conveniencia al comprador" [13.octubre.1758]. 
Constantinopla, cuarto principal" [15.marzo.1758]. Como curiosidad añadiremos que la venta de pinturas era también cuestión de mujeres. Ya hemos citado la mujer que vendía verdura; además se puede añadir que "en la calle de Cantarranas, casa del Cristo al cuarto principal" vivían "dos mujeres que veniden diferentes Pinturas originales de varios autores" [20.febrero.1758]. Entre las aclaraciones que a veces insertaba el periódico se encuentra la siguiente: "El cuadro que se dijo en el Diario 23 febrero que vendía Juan Angel de Mollinedo, mercader de paños, junto al pasadizo de San Miguel fue equivocación de quien dirigió la esquela, le vende Teresa de la Cuesta viuda de Juan de Salas que vive en la escalera de dicho pasadizo, a tres altos". Hasta los sacristanes se encargaban de estos menesteres, por lo menos el del Oratorio del Espíritu Santo de la calle de Valverde ocupaba su tiempo en ello [30.septiembre.1768].

Madrid, como es lógico, era el principal centro del país en el consumo de bienes de arte. Hemos visto ya cómo la serie de pinturas de la Vida de la Virgen, de Tobar o Murillo, había sido traída a la Corte, por eso no extraña que se insertara en el Diario Noticioso la siguiente noticia comercial procedente de Roma:

La compañía de Pintores de la Escuela Romana que está bajo del cuidado de Alice y Benucci, ofrece servir a cualquier persona que tuviere gusto de buenas pinturas con los cuadros siguientes: Primeramente por un cuadro de Historia sagrada o profana de 12 palmos de largo y 8 de ancho de medida romana pintadas en el desde 7 hasta 12 figuras se dará por 100 escudos romanos que son 2.000 rs. vellón, por otro del mismo tamaño con 4 a 7 figuras 80 escudos que son 1.600 reales de vellón, por otro de las misma grandeza desde una hasta 4 figuras por 60 escudos que son 1.200 rs., por otro de la misma altura y ancho, de marina, paisaje perspectiva y arquitectura con figuras pequeñas, se dará por 50 escudos que son 1.000 rs. Ofrece asimismo servir con otros tamaños desde la medida dicha hasta una tercia o como lo quieran por precios muy acomodados y guardando en el dibujo todas las leyes de perfección y buen gusto [5.marzo.1758].

Sobre los precios de tasación y venta es mínima la información, es de notar que aparezca el precio convertido a reales en el aviso de la compañía romana de pintores, pero hay que tener presente que en última instancia había que hacerlos traer a Madrid. Entre los escasísimos ejemplos vimos la lámina de Rafael tasada en 18.000 reales y el Ecce-Homo de medio cuerpo de Tiziano que fue valorado en 100 doblones. Este último se daba junto a otra pintura apaisada - no da el tema-, tasada en 200, pero cabe suponer que fuera de tema profano pues se ofrecía junto a una pintura de "Venus y Mercurio dando lección a Cupido [...] cuyo autor se ignora", que valía esa misma cantidad, mientras que otra original de autor famoso pero con el tema de Santa Gertrudis había sido tasada 
como el Ecce-Homo [16.marzo.1758]. Existen algunos casos más: en la calle "de la Abada frente del Molino de Chocolate, entre un Peluquero y un Zapatero en el cuarto de don Manuel Acebedo y Lira daran razón de un sujeto que vende una lámina de cobre, de una vara de alto y el ancho correspondiente que representa la Imagen de J.S. Señor nuestro [no se expresa en que actol y a San Ignacio de Loyola, guarnecida con marco dorado de toda moda, se previene es original del Teatino [Daniel Seghers], tasada en 3.000 rs. vellón" [19.septiembre.1758]; el 7 de marzo de 1759 se ponían a la venta dos pinturas "la una representa los Desposorios de San José y la otra el Nacimiento, su autor Valdepere, tasadas en 3.000 reales, que se han dado de limosna a la Madre Santísima de la Luz de la Iglesia de San Millán, darán razón de ellas en casa de Manuel Diaz, cofrero junto al Colegio Imperial y en la de Juan Tamayo, sillero que está en frente de dicha iglesia". Finalmente, el 12 de marzo de 1766 "en la calle de los Reyes en casa de don Manuel Cecilio Sainz preceptor de gramática se venden dos lienzos pinturas de fábulas cada uno de tres varas de largo y media de ancho tasado cada uno en 300 rs. vn...

Del cliente de los objetos de arte apenas nada se deduce de las páginas del Diario, aunque fueran los mismos que leían la publicación, comerciantes y profesionales acomodados que habitaban en Madrid. Las mujeres tendrían un papel activo al tratarse de objetos para el adorno doméstico, el mismo Goya en su descripción indica que es el prendero quien trata con una señora. La visión de la casa era muy distinta entre hombres y mujeres, también entre Goya y su esposa. Por eso, si comenzabamos estas líneas con la visión goyesca de las ferias como lugar para comprar objetos de arte, también a él podemos remitirnos para comprender la diferente visión que tenían de la casa ellos y ellas en esta época. Así escribía el pintor a su amigo Martín Zapater el 21 de julio de 1780: «Para mi casa no necesito de muchos muebles, pues me parece que con una estampa de Nuestra Señora del Pilar, una mesa, cinco sillas, una sartén, una bota y un tiple y asador, y candil todo los demás es superfluon. En estos términos encargaba a Zapater que le buscara vivienda ante el inminente traslado a su ciudad natal con la familia. Poco después volvía al tema: "Acerca de la casa veo que nos prestas todo el servicio que puedes; también mi mujer te los estima infinito y me encarga que te diga que como es la sepultura de las mujeres la casa..." (Canellas 1981: 224). 


\section{BIBLIOGRAFÍA CITADA}

BoyD, A. (ed.) 1954. The Journal of William Beckford in Portugal and Spain 17871788. Londres.

Canellas LóPEz, A. 1981. Francisco de Goya. Diplomatario. Zaragoza: Librería General. Caro Baroja, J. 1985. La hora navarra del XVIII (Personas, familias, negocios e ideas). Pamplona: Comunidad Foral de Navarra.

CASANOVA, G. 1982. Memorias. Madrid: Aguilar.

CuETO, L. A., Marqués de Valmar. 1893. Historia crítica de la poesía castellana en el siglo XVII. Madrid.

E. V. H. 1959. "Almoneda. [1758-1814 (Diario de Madrid)", Arte Español, XXII: 189-205. FisCHER, C. A. 1802. Travels in Spain in 1797 and 1798. Londres: Fongman y Rees.

Glendinning, N. 1992. Goya. La década de los Caprichos. Retratos 1792-1804. Madrid: Real Academia de Bellas Artes de San Fernando.

- 1996. "El arte satírico de Los Caprichos; con una nueva síntesis de la historia de su estampación y divulgación", en Caprichos de Francisco de Goya. Una aproximación y tres estudios. Madrid: Calcografía Nacional.

GLENDINNING, N., E. HARRIS y F. RUSSELL. 1999. “Lord Grantham and the Taste for Velázquez, the 'Electrical Eel' of His Day", Burlington Magazine, 1.159 (octubre): 598-605.

Herrero, C. 1996. "La Real Fábrica de Tapices de Madrid y las innovaciones en tiempos de Francisco de Goya", en Realidad y sueño en los viajes de Goya. Actas de las I Jornadas de Arte de Fuendetodos. Zaragoza: Ediciones de Fuendetodos.

JunQuera, J. J. 1979. La decoración y el mobiliario de los palacios de Carlos IV. Madrid: Organización Sala Editorial.

MARTín GAITE, C. 1981. Usos amorosos del dieciocho en España. Barcelona: Editorial Lumen.

MOYa VAlgañón, J. G. 1997. "Las láminas recortadas del Quijote de la Colección Real", Reales Sitios, 133: 60-67.

Oman, Ch. C. y J. Hamilton. 1982. Wallpapers. A History and Illustrated Catalogue of the Collection of the Victoria and Albert Museum. Londres.

PONZ, A. 1772-3. Viaje de España. Madrid: Imprenta de Ibarra, t. I y II.

PORTús, J. 1997. "Cuando ya no hay palabras: El "no sé qué" y otras fórmulas de lo inefable", en M. MORÁn TURINA y J. PORTús, El arte de mirar. La pintura y su público en la España de Velázquez: 157-173. Madrid: Istmo.

PORTús, J. y J. VegA. 1998. La estampa religiosa en la España del Antiguo Régimen. Madrid: Fundación Universitaria Española.

SARRAILH, J. 1974. La España Ilustrada de la segunda mitad del siglo XVIII. Madrid: Fondo de Cultura Económica.

SECRETOS. 1807. Secretos raros de artes y oficios. Madrid: Imprenta de Villalpando.

SEMPERE y GUARINOS, A. 1788. Historia del lujo y de las leyes suntuarias de España. Madrid: Imprenta Real.

Tommlinson, J. 1993. Los tapices de Goya. Madrid: Cátedra.

Twiss, R. 1999. Viaje por España en 1773. Madrid: Cátedra. 